Est Ag 42 (2007) 139-177

\title{
La ideología popular y la reacción islámica
}

\author{
Un ensayo sobre la cólera contra las caricaturas de Mahoma
}

En su famosa novela, Il nome della rosa, Umberto Eco había ya afirmado de nuevo el juicio popularmente aceptado desde la antigüedad en relación de la religión: a pesar de su poderosa dimensión social, la religión no sufre las burlas. Reírse de ella, equivaldría a invocar el juicio de muerte sobre uno mismo. Este había sido el destino del bibliotecario Malachia (Malaquías) quien, como muchos otros, aparece muerto al final de la novela ${ }^{1}$. Aún cuando se acepta sin crítica alguna este estado de cosas propio de la sociedad cristiana del medioevo, nadie parece dispuesto a ignorar las protestas musulmanas contra las caricaturas de Mahoma. Además se argumenta que aquí se trata de una cuestión fundamental: el derecho a la libre expresión. ¿Es una cuestión de derechos? ¿En qué se fundan estos derechos? ¿Hay derechos que no tienen ninguna restricción? ¿Por qué sólo ahora se reivindican estos derechos? De hecho, son numerosas las infracciones que, contra esos derechos, han tenido lugar en países islámicos y no-islámicos.

Obviamente para comprender la reacción islámica hay que sobrepasar el contexto religioso. El horizonte político-ideológico en que se encuentra el Islam hoy juega aquí un papel importante. Además, las caricaturas mismas representan una situación en la que Occidente se siente forzado a implicarse. Reducir la reacción a una simple cuestión de derechos equivaldría, pues, a confiar este complejo asunto a un legalismo sin sentido. Por eso, en este artículo

1 Naturalmente la falta de seriedad y la desordenada curiosidad, junto con la propensión al humor, son los pecados de los muertos de la novela. Pero Eco destaca la importancia que se concedía al no-reír en el ámbito sagrado-religioso. Desde la perspectiva de Jorge de Burgos (guardián de este valor en la novela), todos estos buscaron los relatos/libros en los que la creación de Dios era objeto de risa, y así disminuían su significado: "Attribuisce la creazione del mondo al riso divino". UMBERTO ECO, Il nome della rosa (Milano: Bompiani, 1980), p. 471 [El nombre de la rosa (Barcelona: Círculo de lectores, 1987), p. 424]; 467-482 para el argumento completo. 
buscaremos explicar el fenómeno fundamentalista/reaccionario sirviéndonos del concepto de la ideología popular (Völkische Ideologie) que tuvo gran influencia en la Europa de los años treinta. Algunos aspectos de esta ideología nos facilitarán ver también el papel importante que tiene la religión hoy. Desconocerlo sería desalojar la religión de la sociedad (II). Como intentos de aniquilar la religión juzgan los musulmanes especialmente los discursos sobre democracia, derechos humanos, igualdad de género etc., promocionados por Occidente. Al parecer, aquí se trata de una cuestión fundamentalmente religiosa: si la religión es solamente una ética intersubjetiva o algo más. Es imprescindible responder a la pregunta: ¿en qué consiste la religiosidad? Aun cuando este ensayo no busca resolver esta problemática, parece necesario introducirla, pues todo grito en favor de los derechos, tácitamente desconoce esta dimensión central que, aparentemente, falta en las protestas (III). Pero, ¿carecen realmente las protestas de esta dimensión de religiosidad? ¿Son únicamente expresiones contra una tolerante intolerancia en nombre del estado abierto? O mejor, ¿son signos iniciales de la intolerancia totalitaria que el Islam entre otras religiones esconde? Para dar una respuesta contundente sería necesario examinarlas. La plataforma popular ofrecida por las múltiples y a veces violentas protestas puede servirnos entonces de punto de partida para investigar sobre el valor religioso. Desde esta perspectiva de los valores es posible descubrir los aspectos comunes que todo hombre comparte en la sociedad. No hay que olvidar que tanto las caricaturas como las protestas son síntomas sociales que la sociedad contemporánea produce en su afán por ser pluralista (I). Son, pues, gemidos de una forma de vida emergente, y eso es razón suficiente para que nos dirijamos con atención a ellos. Si no los tomamos en serio, corremos el riesgo de destruir la sana convivencia social.

\section{Una persona de fe puede tanto como mil de sólo intereses *}

\section{Crónica de una violación}

Las doce caricaturas de Mahoma que provocaron las protestas recientes se publicaron el 30 de septiembre de 2005 en Dinamarca. El diario Morgenavisen Jyllands-Posten que encargó y publicó las imágenes tenía, según el editor cultural Flemming Rose, la intención no solamente de denunciar el ciego terrorismo 'promovido' por y en el nombre del Islam, sino también de abrir

\footnotetext{
* JOHN StUART MiLl, "One man with beliefs is equal to a thousand with only interests".
} 
un diálogo serio entre los creyentes moderados musulmanes y daneses. En el artículo que acompañó las caricaturas Rose expresó estas opiniones y en un comunicado posterior cuestionó también la postura de privilegio que reclaman los musulmanes en Occidente: "Algunos musulmanes rechazan la sociedad moderna y secular, exigen un status especial que tome en consideración sus sentimientos religiosos. Es una postura irreconciliable con la democracia secular y la libertad de expresión, donde uno debe aceptar que puede ser objeto de burla, mofa y ridículo"2. El contexto de este cuestionamiento es complejo pero fácil de describir, al menos por lo que concierne a los últimos cincuenta años. Comenzamos por lo más cercano y reciente.

\section{I.1. Contra la complacencia con el mal}

Especialmente después del ataque terrorista del 11 de septiembre de 2001 en Nueva York, del catastrófico atentado del 11 de marzo de 2004 en Madrid, y de los no del todo logrados ataques de 7 y 21 de julio de 2005 en Londres, Occidente teme con razón cualquier amenaza que venga en nombre del Islam ${ }^{3}$. El caso del Theo van Gogh (asesinado el 2 de Noviembre 2004) y del Salman Rushdie (condenado bajo fatua en 1989) -por mencionar solo algunos casos más conocidos- han demostrado que el integrismo islámico no rehúsa aniquilar a cualquier persona que le cuestiona, ridiculiza o que, a su parecer, se opone a su ideología. Desde esta perspectiva es fácil comprender porqué los editores del Jyllands-Posten vieron que existe una tácita complacencia con el integrismo islámico al menos como auto-censura, cuando nadie se atrevió a ilustrar un libro sobre Mahoma de la autora danesa de libros infantiles Kaare Blutigen. La reticencia a pronunciarse contra el integrismo islámico o, mejor dicho, el temor a hacerlo se evidenció también con ocasión de la publicación del libro Yo acuso de la diputada holandesa Ayaan Iris Ali, de origen somalí: los traductores europeos del libro exigían que no figurasen sus nombres al lado del de la autora en la cubierta 4 . En otros casos semejantes los retiraron de exposiciones o cancelaron programas teatrales ya anunciados en

2 Pedro Poza Maupain, "El cruzado danés" (El mundo, año 17, n. 536, “Crónica”, domingo 5, febrero, 2006) p. 7. Varios artículos relacionados con el tema se encuentran en el sitio web de Jyllands-Posten: www.jp.dk/indland/ Este ensayo recoge también esta fuente entre otras.

3 Entre los varios estudios que analiza la situación musulmana en Occidente, véase esp.: Ron GEAvEs, Theodore Gabriel, Ivonne Haddad \& Jane Idleman Smit (eds.), Islam \& The West Post 9/11 (Hants, U.K.: 2004).

${ }^{4}$ En la edición española figura el nombre de la traductora en la página interior. 
Londres, Gotemburgo y Amsterdam5 5 . Optar por el silencio ante la encubierta invasión del derecho personal de expresión, argumentan Rose y compañía, sería favorecer y potenciar las manos del totalitarismo integrista. Por eso decidieron publicar las caricaturas de Mahoma.

Y como se esperaba, la publicación se encontró con la protesta de la comunidad musulmana danesa que exigía una disculpa al diario y organizó una manifestación en Copenhague el 14 de octubre de 2005. El asunto impulsó también a 11 embajadores de países islámicos a pedir la intervención del Estado danés contra Jyllands-Posten, que, sin embargo, quedó sin éxito dado que la publicación era completamente legal en Dinamarca. Observamos que las autoridades políticas desconocían o, al menos, rehusaban admitir en público que no se trataba de una cuestión legal sino de sentimientos religiosos, imagen, identidad y sobre todo de poder. Mientras el editor del diario defendió la publicación por razones éticas, culturales, etc., se lamentó de la ofensa no intencionada causada por ella y no pidió disculpas por la publicación 6 . Una delegación de musulmanes daneses (liderada por el imán Abu Laban, un inmigrante palestino ${ }^{7}$ ) buscó el apoyo de los hermanos en la fe contra las caricaturas ofensivas, incluso contra las no publicadas (pero que el periódico tenía en su posesión). La campaña musulmana de los meses de noviembre-diciembre del 2005 produjo varios resultados: La Liga Árabe criticó al primer ministro danés por su mala gestión del caso; la asociación internacional de eruditos musulmanes llamó al boicot comercial que comenzó el 29 enero en Arabia Saudí; y el editor del diario Jyllands-Posten, Carsten Juste, se sintió obligado a pedir disculpas por la publicación, visto que hay "vidas humanas en juego"8.

Aun cuando parecía que la disculpa había calmado la cólera, la violenta y politizada reacción contra las caricaturas sólo había comenzado. La protesta no faltó en los países mayoritariamente musulmanes y en otros con una

5 Para más detalles sobre estas y similares acciones, véase: "La historia" en: www.jp.dk/indland/; también: "Everyone is afraid to criticize Islam", entrevista con Ayaan Iris Ali en: Spiegel, Feb. 6, 2006.

6 'No publicar las caricaturas sería defraudar a los musulmanes moderados y a los que luchan contra la represión en el mundo islámico,' opinó el editor. Véase: "El editor y las 12 caricaturas" entrevista por John Hansen, publicado el 18 de diciembre de 2005, www.jp.dk/indland

7 Véanse: $A B C$, viernes $10 / 2 / 2006$, p. 34; sábado $11 / 2 / 2006$, p.36.

${ }^{8} \mathrm{La}$ carta de disculpa del editor y la explicación sobre lo que le motivó se encuentran en el sitio web del diario (www.jp.dk/indland/) bajo los títulos: "Honorables conciudadanos del mundo musulmán", publicado el 30 de enero de 2006; "El dilema del editor", entrevista por Pierre Collignon, publicado el 5 de febrero de 2006; véanse también: "El periódico danés que publicó las sátiras se disculpa en seis idiomas", $A B C$, viernes 10/2/2006, p. 35. 
población significativa (como p. e. la India que, con sólo el 13.4 \% de sus habitantes, constituye la segunda nación con más seguidores del Islam). Lo que sobresale en este hecho es la forma: violencia contra sedes diplomáticas, representaciones oficiales, boicoteo de productos daneses y occidentales, ataques contra cristianos, invitación pública a asesinar a los autores de las caricaturas, oferta de dinero para cometer actos violentos contra todo lo que apareciera asociado a las caricaturas, etc. ${ }^{9}$ ¿Cómo se justifica una reacción tan desproporcionada contra unos dibujos? Además, ¿los protestantes han visto o han comprendido las caricaturas? Los editores del Jyllands-Posten reconocen hoy que nunca imaginaron que fuera posible una reacción tan violenta y global. ¿Fallaron en su juicio sobre el Islam? O. ¿desconocieron la importancia que los fieles atribuyen a la figura de Mahoma? $\mathrm{O}$ ¿quizás fueron los musulmanes manipulados localmente por pura ideología política? ¿Hay alguna justificación para la violencia contra los inocentes, por ejemplo los cristianos nigerianos, que no son ni suscriptores ni lectores del implicado diario danés? ¿Se puede comprender la violencia organizada en nombre del Islam? Más adelante analizaremos las respuestas dadas especialmente por la prensa española. Por el momento, sería necesario ampliar el horizonte colocando la cólera contra las caricaturas en una dimensión global, pues, como ya hemos visto, sus efectos desbordaron las fronteras territoriales danesas.

\section{I.2. Terroristas, verdugos y efectos colaterales}

En su libro Sacred Rage, Robin Wright argumenta que, frente al extremismo islámico, Occidente cometió al menos dos errores: el primero, el comenzar a reaccionar sólo después que los occidentales fueron víctimas; el segundo, equiparar a los chiítas con los terroristas, aun cuando el fundamenta-

\footnotetext{
${ }^{9}$ Para hacerse una idea, bastaría echar un vistazo a los titulares en los diarios del mes de Febrero de 2006. No pasó un día sin que se refirieran a las caricaturas. He aquí algunos ejemplos tomados del periódico $A B C$ : "La «Mahoma-krisen»", (viernes 3, p. 39); "«Viernes de ira» y de guerra santa contra Europa en mezquitas de todo el mundo" (sábado 4, p. 38); "La quema de embajadas llega al Líbano en un peligroso efecto dominó" (lunes 6, p. 34); "Mueren cinco personas en otra jornada de cólera musulmana que llega a Irán y Afganistán”, (martes 7, p. 39); "El turco que mató al sacerdote italiano estaba «furioso por las caricaturas»", (miércoles 8, p. 37), etc. En la página dedicada a la crisis de las caricaturas $E l$ Norte de Castilla (19 de Febrero 2006, p.37) informó: Quince muertos y once iglesias cristianas quemadas en una protesta en Nigeria; Un ministro indio ofrece 11,5 millones de dólares por la cabeza de los dibujantes. El mismo periódico con la fecha 16 de febrero del 2006 informa: "La violencia contra las viñetas en Pakistán causa otros tres muertos", p.30.
} 
lismo floreció igualmente entre los sunitas ${ }^{10}$. Pero, ¿cuál fue la causa de esta reacción extremista de los años 80 que continúa hasta hoy? La respuesta más adecuada sería ver en ello la re-emergencia o el renuevo de las más radicales y fundamentales aspiraciones del Islam, lanzadas especialmente por la revolución iraní al menos desde 1979.

Wright señala justamente que mientras la facción triunfante y poderosa del ayatolá Jomeini no descartó la conquista islámica de Occidente, aún por medio de mártires suicidas, la gente común se ilusionó con la prometida erradicación de la injusticia y la discriminación entre los musulmanes ${ }^{11}$. Sin duda el último aspecto se ubica perfectamente dentro del primer período del Islam: sus orígenes desde la Meca. Ese aspecto religioso, la dimensión de la justicia, no solamente legitima sino también unifica los movimientos islámicos tanto radicales como moderados, dando a la religión misma una nueva/renovada identidad. Desde esta perspectiva, se debería considerar la revolución iraní como una continuación de la revolución francesa y/o rusa; además se pretende que el Islam ofrece una tercera vía en contraste con la de Occidente (cristianismo) y del Oriente (hinduismo, confucianismo, etc.). En todo caso, es llamativa la fundación de la revolución en el yihad cuyo significado entre los militantes coincide más y más con la lucha armada para la independencia y/o el establecimiento del Dar-al-Islam (el universo islámico) ${ }^{12}$.

¿Cómo se llega a esta interpretación del Islam, donde por un lado dan gran valor al militarismo y por el otro se sienten víctimas? A manera de respuesta, Wright nos pone el ejemplo de Hamza, un chiíta libanés que en 1982 asaltó un avión que volaba de Trípoli a Beirut para forzar la liberación del imán Musa al Sadr, líder espiritual de los chiítas en Líbano y colega del ayatolá Jomeini, supuestamente encarcelado por el coronel Gaddafi de Libia. La transformación de Hamza -quien en otras condiciones hubiera seguido la carrera de ingeniero o médico formado en Occidente- en líder militar del grupo Amal $^{13}$, está marcada por la guerra civil libanesa (1975-76); su militancia desde entonces ha sido en pro de la identidad chiíta característica de la revolución iraní. En ambas etapas, la causa belli se identificó como lucha contra la injusticia y defensa del Islam que podría abrazar a los Palestinos y a otros pueblos 'oprimidos'. Aquí está la firme convicción que el verdadero Islam

10 RoBIn Wright, Sacred Rage: The Wrath of Militant Islam (New York: Simon \& Schuster, 2001), pp. 19-20.

11 R. WRIGHT, Sacred Rage, pp. 26-45.

12 Sobre este aspecto, véanse más adelante, II.2.2 \& II.2.3. Para favorecer una lectura más ágil, las palabras árabes sólo llevan los signos diacríticos en las citas y para clarificación.

13 Afwaj al Muqawimal al Lunaniya: batallón de resistencia libanesa. 
promueve la igualdad entre los hombres, y el verdadero musulmán debe esforzarse en cumplir la voluntad de Alá14.

El tenor del análisis de Wright toma dos direcciones, una política y otra religiosa, y saca una conclusión clara: los musulmanes en general se sienten perdedores y conquistados especialmente desde el colonialismo europeo que les convertía en víctimas ${ }^{15}$; una salida a esta situación será la religión concebida en sentido radical. Indicios de un posible éxito islámico lo constituye la unidad creada durante la guerra contra Israel en 1973, la decisión unánime de emplear el tema económico, cuadruplicando por primera vez el precio del petróleo, y finalmente la revolución iraní que reivindica a los chí́tas dentro del mismo mundo musulmán. El mensaje es: el Islam está comenzando a resarcirse globalmente, y este proceso consiste en hacerse sentir tanto política como religiosamente ${ }^{16}$. La conclusión es que en la actualidad tenemos que confrontarnos con un movimiento renovador islámico, no simplemente con un grupo ideológico o terrorista ${ }^{17}$. Imágenes de esta aspirada renovación manchada de cólera y sangre la encontramos en Líbano, Kuwait, Israel, etc. y en Nueva York desde el 11 de Septiembre.

A pesar de ello, no debemos ignorar la auténtica renovación dentro del Islam representada, por ejemplo, por el ayatolá Yusef Saanei en Irán. Según ella, la igualdad entre los hombres forma parte central del credo musulmán, y cualquier discriminación basada en género, etnia, etc. debe ser rechazada por el verdadero Islam. Por ello el yihad debe ser un esfuerzo por perfeccionarse a sí mismo, aplicable a todos los aspectos de la vida, incluido el social. Una tarea imprescindible que atañe a todo el Islam sería entonces la eliminación de desigualdades, pobreza, corrupción, injusticia, etc. Según esta perspectiva alternativa, los fundamentalistas han asaltado el Islam ${ }^{18}$. La renovación islamista, aún teniendo aspectos integristas, es una verdadera alternativa que Occidente debe tomar en cuenta ${ }^{19}$. La cólera expresada contra las caricaturas

${ }^{14}$ R. WRIGHT (Sacred Rage, p. 62) cita a Hamza: “... Islam makes equality to all the people, true Islam, not the kind in Saudi Arabia"; "To be a Muslim is not simply a matter of individual will; it means participating in the effort to implement God's will on earth".

15 Cómo el yihad servía contra el colonialismo lo explica: RudOLPH PETERs, Islam and Colonialism. The Doctrine of Jihad in Modern History (The Hague: Mouton, 1979), pp. 39104.

16 Véase: ibíd., pp. 46-68; para la entera historia: capítulos: 4-9.

17 Según Wright (Sacred Rage, p. 278), estos movimientos islamitas se parecen a la teología de la liberación.

18 Véase: R. WRIGHT, Sacred Rage, p. 280 y ss. Esta tesis que se encuentra en Occidente, en general, la aceptan también los musulmanes que se consideran progresistas. Nos ocuparemos de esta perspectiva en las secciones segunda y tercera.

19 Véase: R. WRIGHT, Sacred Rage, p. 287 y ss. 
manifiesta también la desilusión de Occidente, incapaz de percibir la transformación religiosa que está teniendo lugar en el mundo islámico. Pero, ¿es convincente la tesis de que los integristas asaltaron el Islam mismo? ¿No es quizás una postura que inconscientemente rechaza confrontar el Islam con sus atrocidades y su 'arcaico' credo?

\section{I.3: EI Islam asaltado y la integración musulmana}

La tesis mencionada, según la cual el Islam se encuentra hoy bajo el mando de los radicales, defendida tanto por la política contemporánea occidental como por la autoridad musulmana, la rechaza totalmente A. Hirsi Ali. Sus razones se basan en argumentos teóricos y en relatos de experiencia personal. Ambos tienen una importancia especial, pues sirven para iluminar una problemática muy compleja con matices religiosos, políticos, sociales, etc. Además, su condición de mujer y delegada del parlamento añade un valor a su postura que también es compartida por otros musulmanes occidentales ${ }^{20}$.

La postura de Hirsi Ali se dirige esencialmente a tres asuntos: integración, ilustración y progreso 21 . A pesar del hecho de que más de 25 millones de musulmanes viven en Occidente, gozan una vida económica y políticamente mejor que en sus países de origen, siguen estando poco integrados en la sociedad que les acogió. Indicios de este aislamiento son tanto el alto número de varones en la cárcel y de mujeres en centros de acogida, como el analfabetismo y la carencia de formación entre los musulmanes en general. La falta, o mejor dicho, el rechazo a la integración se explica por la ignorancia y la carencia de crítica de su propia fe. Eso conduce a los inmigrantes a percibir a Occidente como "el mundo al revés"22. Pues, argumenta Hirsi Ali, "los principios básicos del islam [jsic!] tradicional, colmados de viejas costumbres del grupo étnico específico, chocan frontalmente con valores y normas elementa-

20 En Mayo de 2006 Hirsi Ali cesó de ser diputada del parlamento holandés y tuvo que abandonar su país de adopción por infracciones relacionadas con su solicitud de refugio político; este acontecimiento lleno de intereses políticos partidarios solamente aumenta su popularidad. Véase: MARLISE Simona, "Muslim's Loss of Dutch Citizenship Stirs Storm" The New York Times (Edición Internet), de 18 Mayo, 2006.

21 Para su postura me baso principalmente en la colección de artículos: AYAAN HIRSI Ali, Yo acuso. Defensa de la emancipación de las mujeres musulmanas (Barcelona: Círculo de Lectores/Galaxia Gutenberg, 2006).

22 A. Hirsi Ali, Yo acuso, p. 32. En contrario opina Abu Laban, imán jefe de la Comunidad Islámica de Dinamarca, $(A B C$, jueves $9 / 2 / 2006$, p. 36) que a la integración debe preceder la definición de las comunidades, sino es perder el tiempo. 
les de la sociedad holandesa"23. Todo ello reclama, entonces, una ilustración musulmana.

El Islam necesita la ilustración tanto para salvaguardar los valores humanos promovidos en la sociedad occidental como para actualizar la fe misma. Los valores que Occidente enfatiza son "la autonomía y la responsabilidad del individuo, y la necesidad de invertir en esta vida terrenal. La educación y el trabajo son símbolos de éxito, y no la devoción de un individuo"24. Tanto el pluralismo, la igualdad ante la ley, la libertad individual (también en cuestiones de sexo y matrimonio), y la igualdad de género como las instituciones políticas y jurídicas que fomenten y protejan estos valores son parte característica de la sociedad occidental. La ilustración propuesta debe aportar estos valores e instituciones a la sociedad musulmana. Además, el Islam ilustrado pondrá mucho más énfasis en la razón que en la fe. Pues: "El conocimiento de la razón liberaría el espíritu del individuo-musulmán del yugo del más allá, de los continuos sentimientos de culpa y de la tentación del fundamentalismo"25.

¿Cómo o de dónde puede venir esta Ilustración? Según Hirsi Ali, “es improbable que una Ilustración se origine en el interior del mundo islámico. Escritores, científicos y periodistas que ejercen la crítica son obligados a huir a Occidente"26. Por ello, la deseada ilustración sería la tarea de los musulmanes occidentales quienes merecen è apoyo de Occidente. En realidad, Occidente parece neutralizar las voces de los disidentes en cuanto considera "la crítica al mundo islámico, a Palestina y a las minorías islámicas" como "islámofoba y xenófoba"27. Esta postura de 'relativismo cultural' es idéntica al racismo, a la aniquilación del progreso y al desconocimiento de la dignidad de los inmigrantes como personas.

Si esta perspectiva crítica de Hirsi Ali tiene razón, estamos frente a dos visiones, al menos, del Islam: una representada por los estados musulmanes y la mayoría del mundo islámico, la otra propuesta por los así llamados musulmanes progresistas, una gran parte de los cuales vive en Occidente. La cólera contra las caricaturas toma un significado más que emocional: indica cómo se percibe el Islam, si se admite una ilustración y crítica de la religión, y sobre todo qué debe ser la religión para el hombre. La reacción musulmana tanto de los progresistas como de los integristas se presenta como lucha contra el

23 A. HiRsi Ali, Yo acuso, p. 45.

24 A. Hirsi Ali, Yo acuso, p. 32.

25 A. Hirsi Ali, Yo acuso, p. 34.

26 A. Hirsi Ali, Yo acuso, p. 33.

27 A. Hirsi Ali, Yo acuso, p. 11. 
mal; una complacencia con el mal vieron los editores del diario Jyllands-Posten en la actitud no-crítica hacia al Islam.

\section{II : En búsqueda de identidad}

En páginas anteriores hemos señalado algunos factores significativos para comprender mejor el complejo contexto de la protesta musulmana contra las caricaturas de Mahoma. No es solamente una expresión de la desilusión contra la sociedad occidental que desconoce las aspiraciones musulmanas ${ }^{28}$ y por eso impone sus criterios de integración, sino también de la determinación y confianza islámica de poderse situar dentro y contra el mundo noislámico. Mientras el primer aspecto se coloca fácilmente dentro a la sociedad multicultural promovida al menos por una facción significativa del mundo occidental que ilumina así los desafíos implícitos en esta ideología política, el segundo exige a los musulmanes definirse de nuevo tanto local como globalmente. Pues se trata de la renovación del Islam mismo, basada en valores propios como fe, justicia, yihad, etc. Las tendencias del Islam contemporáneo, antes mencionadas, se relacionan con esta deseada renovación y buscan fundamentarla en una identidad adecuada para una religión dinámica y vivida actualmente. En consecuencia, propongo la tesis de que las protestas contra las caricaturas de Mahoma defienden la ideología popular que se encuentra en lucha contra la imagen progresista del Islam. Como la reacción de la prensa en general no toma esta distinción en consideración, desconoce lo esencial, lo religioso, y, en consecuencia, reduce la cuestión a un simple asunto de derecho. Este análisis de los tres puntos mencionados -musulmanes progresistas, ideología popular y la reacción de la prensa- nos conducirá en el apartado siguiente a la cuestión de la religiosidad.

\section{1. Musulmanes progresistas y la ideología popular}

Los musulmanes progresistas constituyen un grupo que reconoce la crisis en que se encuentra hoy el Islam, y busca reafirmar la justicia, la bondad y

28 Véase: Antonio CAÑo, "La última frontera de Europa", El País, 10 de abril de 2006, pp. 14-15. "En Dinamarca, la reciente crisis provocada por las caricaturas de Mahoma tiene su origen, en realidad, en la irritación de la comunidad islámica danesa por el giro propiciado en materia de inmigración por el actual Gobierno conservador danés". Los musulmanes "reclaman, más que subvenciones, una política de igualdad de oportunidades para los inmigrantes", ibíd, p. 14. 
la belleza intrínseca de su tradición 29 . Dispuestos a afrontar la crítica lanzada contra el Islam, problematizan especialmente tres asuntos: la justicia social, el pluralismo religioso y la igualdad de género. La auto-crítica y la renovada reflexión sobre el Islam les permiten situarse entre los grupos extremistas como los conservadores fundamentalistas y reaccionarios integristas. ¿Cuáles son las preocupaciones que habrían cuestionado o vindicado las protestas contra las caricaturas? Antes de nada, los musulmanes progresistas presuponen una seria reflexión y encuentro crítico con la tradición; su perspectiva se funda en el Islam y se inspira en él. Sería entonces bien llamarla ichtihad -"committed critical thinking based on disciplined but independent reasoning"30-, que busca principalmente sanear el pensamiento islámico empobrecido por el exclusivismo literario. Un ejemplo de este pensamiento se da en la argumentación avanzada por Khaled Abou El Fadl.

Reconociendo la grave degeneración del Islam contemporáneo representada especialmente por el ataque del 11 de septiembre y la muerte causada por la rigurosa aplicación de la ley islámica en una escuela de $\mathrm{Mec}^{31}$, Abou El Fadl opina que la teología del poder reina hoy en el Islam. Aun cuando uno puede explicar el Islam contemporáneo como reacción al modernismo y colonialismo europeo y la consecuente opresión y explotación, no debe ignorar la degeneración de la fe causada por los creyentes mismos. Esta consiste principalmente en descartar las investigaciones morales favoreciendo al mismo tiempo una dinámica de poder. Dos factores (el puritanismo y la vulgarización) nos permiten explicar estos fenómenos degenerativos del Islam. La vulgarización consta de varios elementos como la 'disonancia intelectual', la mentalidad de conquista, el dogmatismo, etc. que busca presentar el Islam como ideología nacionalista contra el 'otro', es decir, la hegemonía occidental, para conseguir fines ulteriores por la simple aplicación de principios islá-

${ }^{29}$ Su postura queda bien clarificada en: Omid Safi (ed.), Progressive Muslims on Justice, Gender and Pluralism (Oxford, UK: Oneworld Publications, 2003). Esta sección se basa en los artículos incluidos en este libro. La misma tendencia a que nos referimos está representada por los "nuevos intelectuales en Europa" cuyo perfil se define en diez elementos, véase: JORDI MORERAS "Prólogo" al libro: Tariq Ramadan, El Islam minoritario. Cómo ser musulmán en la Europa laica (Barcelona: Ediciones Bellaterra, 2002) pp. 18-22.

${ }^{30}$ O. SAFI (ed.), Progressive Muslims, p. 8.

${ }^{31} \mathrm{El}$ triste acontecimiento referido tuvo lugar en Marzo 2002 cuando la policía moral mutawwa'un prohibía a unas chicas abandonar la escuela en llamas sin vestirse según la ley musulmana, y por eso muchas fueron víctimas del fuego. Véase: KHALED ABOU El Fadl, "The Ugly Modern and the Modern Ugly", en: O. SAFI (ed.), Progressive Muslims, pp. 33ff;; notas 1 y 2 en p. 63 dan una amplia bibliografía sobre el asunto, como p. e. "They Died for Lack of a Head Scarf," Washington Post, Marzo 19, 2002, A21; "Cleric sacked over Saudi School fire", http://news.bbc.co.uk, lunes 25 de Marzo de 2002. Recientemente, el gobierno Saudí anunció alguna modificación de esta vigilancia moral. 
micos y así asfixiar cualquier tipo de encuentro serio y crítico con la tradición. Un paso significativo de esta vulgarización ha sido la aniquilación de las instituciones de autoridad religiosa islámica. Esto no solamente derrotó toda crítica legítima del Islam sino que también creó un vacío dejando en la oscuridad quién y cómo actúa la autoridad religiosa. Las autoridades religiosas tradicionalmente no partidarias, no del todo autónomas ni descentralizadas, llegan a transformarse en la modernidad, bajo el control de los estados islámicos, en funcionarios e intérpretes del código civil al servicio no de la tradición islámica sino de ideologías nacionalistas y anti-imperialistas o anticoloniales. Esta desintegración de las instituciones islámicas de enseñanza y pensamiento hace surgir tanto la autoridad autodidacta como la apología vulgar ${ }^{32}$, que facilitó la ideología nacionalista anticolonial pero también puritana, supremacista y totalmente oportunista.

La emergencia y la actual influencia del salafabismo entre los musulmanes permite explicar cómo el puritanismo junto con la vulgarización juega un papel importante en la derrota del pensamiento auténtico islámico ${ }^{33}$. Esta ideología religioso-política se coloca entre el salafismo y wahabismo, y se nutre de ambos. Mientras el wahabismo ${ }^{34}$, buscando corregir el Islam de todo misticismo y racionalismo, adoptó una interpretación estrictamente literal del texto coránico, rechazó perspectivas históricas, contextuales, etc. eliminando las categorías de creatividad e imaginación, desde la praxis hermenéutica, y así se presentó como el auténtico Islam, el salafismo abogó por la vuelta a los

32 Véase: Khaled ABou El FadL, "The Ugly Modern and the Modern Ugly", en: O. Safi (ed.), Progressive Muslims, pp. 43ff. "As such, Islamic intellectual culture witnessed an unprecedented level of deterioration, as self-proclaimed and self-taught experts reduced the Islamic heritage to the least common denominator, which often amounted to engaging in crass generalizations about the nature of Islam, and the nature of the non-Muslim "other." ... Most significantly, as they searched Islam for black-and-white and definitive answers to all their socio-political problems, these Muslim activists superimposed the logic of empirical precision and the determinism of Western scientific methods upon the Islamic intellectual, and particularly the juristic, tradition." Ibid, pp. 47-48.

33 Véase: KHALED ABOU El FADL, "The Ugly Modern and the Modern Ugly", en: O. Safi (ed.), Progressive Muslims, pp. 49-59.

34 Para una introducción al Wahabismo que se desvía de la interpretación ofrecida por K. A. El Fadl, véanse: NATANA J. DELONG-BAS, Wahabi Islam. From Revival and Reform to Global Jihad (Oxford: Oxford University Press, 2004); también: TARIQ RAMADAN, El reformismo musulmán. Desde sus orígenes hasta los Hermanos Musulmanes (Barcelona: Ediciones Bellaterra, 2000), pp. 56-61. Valdría la pena fijarse en la matización ofrecida por Ramadan: Ibn Abd al-Wahhab "intentaba dejar claro a los musulmanes [de su tiempo] que el problema del mundo islámico no residía,... en el mal trato sufrido a causa de la hostilidad de las potencias europeas occidentales o de los «cristianos», sino, en primer lugar, en una falta de fe y, después, en un error de pensamiento, de entendimiento y de inteligencia." Ibíd., pp. 59-60. 
textos y prácticas originales de Mahoma y sus compañeros ${ }^{35}$. Según la autocomprensión de los wahabitas, se relacionan con los no-musulmanes desde una postura dominante: no importa qué piensan los demás de los musulmanes dado que los valores universales son irrelevantes a la misión islámica. Así por la pureza de la fe (expresada por el aislacionismo) los mismos turcos y mongoles ocupan un lugar sólo después de los wahabitas en el mundo islámico; lo mismo vale también en el ámbito del pensamiento y de la autoridad. Es decir, sencillamente, según el wahabismo hay musulmanes de varias categorías jerárquicas y de rangos socio-religiosos que desafían el concepto de igualdad islámica. A pesar de haber idealizado los orígenes del Islam, iniciando una hermenéutica que buscó leer en los textos más antiguos los valores del modernismo y haber puesto gran énfasis en el bien común (maslaha), el salafismo como el wahabismo desaprobó el sufismo (que reconoce y promueve la igualdad ideal) y comprometió principios teológicos para defender la política del poder y el nacionalismo. Ambas tendencias postularon una época dorada del Islam, realizable en un futuro inmediato. Esta ideología que fusiona ambas tendencias se llama salafabismo que no está representada por ninguna institución sino que se apoya en el poder de Arabia Saudita. Según El Fadl, el salafabismo define el Islam como la antítesis de Occidente:

Salafabists argued that colonialism had ingrained into Muslim a lack of self-pride or dignity, and convinced Muslims of the inferiority of their religion. This has trapped Muslims into an endless and futile race to appease the West by proving Islam's worthiness. According to this model, in reality, there are only two paths in life - the path of God or the straight path, and the path of Satan or the crooked path. By attempting to integrate and co-opt Western ideas such as feminism, democracy, or human rights, Muslims have fallen prey to the temptations of Satan by accepting ungodly innovations ... They believe that Islam is the only straight path in life, and such a way must be pursued regardless of what others think and regardless of how it impacts the rights and well being of others. Importantly, the straight path ... is firmly anchored in a system of Divine laws that trump any considerations of morality or ethical normative value. ... According to the Salafabists, lives that are lived outside the Divine law are inherently unlawful, and therefore an offense against God that must be actively fought or punished ${ }^{36}$.

35 Sobre la ideología Salafi, véanse: BEN SALEM HIMMICH, De la formation idéologi que en islam (París: Anthropos, 1980), pp. 193-213; también: T. Ramadan, El reformismo musulmán, pp. 154 y ss.

36 Khaled Abou El Fad, "The Ugly Modern and the Modern Ugly", en: O. Safi (ed.), Progressive Muslims, pp. 58-9. 
Esta es la ideología que ha nutrido y sigue nutriendo las ramas más radicales del Islam, como la de Bin Laden.

\section{II.2. Ideologías populares, ichtihad y yihad}

La vulgarización y el puritanismo que hemos explicado constituyen lo que quiero llamar la ideología popular representada por las protestas contra las caricaturas de Mahoma. Aun cuando ésta se debe contraponer a la rama progresista musulmana, vale la pena recordar que fue una ideología abrazada con entusiasmo también en la Europa cristiana.

\section{II.2.1. Das völkische Denken}

Marcada casi siempre como característica esencial del Tercer Reich, el pensamiento popular (völkisches Denken) se presentó como sabiduría perenne enraizada en la propia tierra. La expresión busca unificar políticamente los dos conceptos -Volk/pueblo y Nation/nación- que en la historia cultural alemana eran distintos ${ }^{37}$. Johann Gottfried Herder fue el primer autor moderno que provee las nociones necesarias para su desarrollo. Según él, los pueblos son los portadores de la historia que la providencia dirige en este mundo, y tienen además sus propias características ya adquiridas desde la creación. El principio de vida en que se basan los aspectos específicos de un pueblo como por ejemplo el idioma, arte, los mitos y costumbres constituye el 'Volk', designado mas tarde como Volksgeist por Hegel. La especificidad del pueblo llega a ser la característica nacional que debe ser conservada en su pureza; pues es divina, distinta, propia de cada pueblo. Herder suscribe el universalismo pluralista sin proponer la superioridad de un pueblo sobre otro ${ }^{38}$, aun cuando considera el cristianismo como meta propuesta por la providencia, ya que cada uno tiene su propio sitio. "Die optimale Organisation der Gemeins-

37 En su sentido étnico, el término pueblo -Volk-se entiende en contraposición de la institución; puede así significar una formación militar que por su función se designa como una clase. Nación -Nation- significaría la unidad étnica dada por nacimiento común. Ambos términos pierden su significado original en tiempo moderno, y los alemanes entendían vivir en países - Länder- bajo regentes extranjeros. El nacional socialismo busca construir una unidad introduciendo conceptos que disminuyen esta divergencia. Al pensamiento popular (Völkisches Denken) llega a ser así el concepto principal unificador. Véase: CoRNELIO WeBER, Altes Testament und völkische Frage (Tübingen: J. C. B. Mohr, 2000), pp. 9-11.

$38 \mathrm{El}$ pueblo Israel tiene un lugar especial por su carácter paradigmático. Sobre su postura, véase: C. WEBER, Altes Testament $u$. völkissche Frage, pp. 12-15. 
chaft liegt für Herder deshalb in dem Staat, der ein Volk umfaßt und somit einen Nationalcharakter besitzt" 39 .

Esta noción romántica que define la identidad nacional por la especifidad de su pueblo experimenta una revisión a través de Schleiermacher y Fichte, causada por la ocupación francesa. Mientras Schleiermacher considera el estado mismo como una institución divina, una etapa superior del pueblo, que posee valores autóctonos, y por lo cual exige ser amado, Fichte concibe a los alemanes como el pueblo más original y ejemplar que por eso debe encargarse de desarrollar la perfección de su imagen ${ }^{40}$. A pesar del acuerdo entre los tres pensadores, se ha de destacar la diferencia, que aunque fina, matiza sus pensamientos. Al poner de relieve el aspecto antropológico, Herder representa una postura apolítica, Schleiermacher favorece el estado institucional y la oligarquía más que el pueblo; y Fichte introduce el contraste con el 'otro' para destacar y ensalzar los valores del pueblo. El espíritu popular tendrá más peso para Herder y Fichte; al contrario que el Estado para Schleiermacher. En estos elementos se basa el pensamiento popular (Völkisches Den$k e n)$, que en el siglo XIX propone una religión nacional alemana ${ }^{41}$. Esta última tendencia no busca nacionalizar la religión cristiana, sino purificarla de elementos judíos y revelados según la necesidad del pueblo alemán. Así se logró establecer la nación soberana fundada en factores naturales, culturales y subjetivos.

Un aspecto decisivo del que no nos ocuparemos -pues ya está estudiado hasta al agotamiento- surge cuando Houston Stewart Chamberlain (18551927) y Langbehn desarrollan el pensamiento popular introduciendo en él los criterios racistas. La concepción del pueblo alemán como la raza superior y la interpretación del pensamiento popular como ideología política fueron los logros de Adolf Hitler y del nacional-socialismo. Ni el hitlerismo ni el nazismo proceden directamente del pensamiento popular aun cuando éste les provee

${ }^{39}$ C. WEBER, Altes Testament u. völkissche Frage,p. 15. Cursiva en el texto; véase también: Hugo Moser, "Volk, Volkgeist, Volkskultur", en: Zeitschrift für Volkskunde 53 (1956/7) 127-140.

40 Para Schleiermacher, Abhandlungen, 260: "Der Staat aber ist die Form des Volkes, das Volk ist nur völlig ausgebildet, wenn sich diese Form rein und vollendet in ihm darstellt". Para Fichte, Grundlage, 179, el pueblo alemán mantiene la pureza de la creación, y por eso "ein Urvolk, das Volk schlectweg". Citado de: C. Weber, Altes Testament u. völkissche Frage, pp. 16-17; véanse también: KEITH W. CLEMENTS, Friedrich Schleiermacher. Pioneer of Modern Theology (London: Collins, 1987), pp. 58-61; Wilfried Brandt, Der Heilige Geist und die Kirche bei Schleiermacher (Zürich: Zwingli Verlag, 1968), pp. 33-46, esp. 41-44.

41 Propusieron esta religión que equiparaba la ley divina con la ley popular especialmente Paul Anton de Lagardes (1827-1891) y su discípulo Julius Langbehn (1851-1909), véase: C. WEBER, Altes Testament u. völkissche Frage, pp. 18-22. 
la base para lanzar su ideología. Ser natural o autóctono confería al pensamiento popular algo místico y mítico; además, le elevaban a la categoría de espiritual y no-individual. Tanto el colectivismo como el naturalismo facilitan al pensamiento popular el ponerse contra el modernismo y la cultura urbanística. La especificidad religiosa y cultural atribuida a la nación surge de los héroes cuyo ejemplo claro es la figura de Nietzsche interpretada, por ejemplo, por Karl Joel ${ }^{42}$.

La búsqueda de identidad nacional coincidió con la identificación y el rechazo del 'otro', como p. e. del judío. Ejemplificado por los escritos de Eugen Diederichs, el entusiasmo por la sociedad enraizada, tradicional y orgánica promovió un nacionalismo ambivalente, en cuanto que el pueblo judío representó el papel de otra sociedad orgánica y paralela aunque legalista e intelectualista. La narrativa popular logró así en las primeras décadas del siglo XX construir al otro según las categorías que imaginaron (dando así razón al argumento avanzado por Edward Said en otro contexto). El concepto 'pueblo/nación' obtiene varias características, entre ellas el aspecto divino que aún los cristianos alemanes no rehúsan totalmente rechazar ${ }^{43}$. Todo esto vale, $m u$ tatis mutandis, también para la ideología popular islámica. Ha de preguntarse entonces si las protestas contra las caricaturas de Mahoma, sostenidas por la ideología popular y en búsqueda de una identidad, no están construyendo por sí mismas al otro en la sociedad occidental. Más aún: ¿se acordó la prensa de esta semejanza entre las ideologías populares y la aspiración musulmana de formar parte de Occidente? Pues a pesar de la conquista ibérica del pasado y la actual inmigración islámica, los musulmanes viven todavía como forasteros en Occidente. Les toca, pues, definir su propia identidad actual.

42 Véase: Robert ElLwood, The Politics of Myth. A Study of C. G. Jung, Mircea Eliade, and Joseph Campbell (Albany: State University of New York, 1999), pp. 22-27. En su libro Nietzsche und die Romantik (Jena \& Lepzig: Eugen Diederichs, 1905), Karl Joel busca presentar a Nietzsche como un guerrero ("Krieger an sich") y un héroe que sabe alzarse sobre todo, y de esta manera conduce al pueblo alemán hacia la grandeza. Interpreta su filosofía vital en este sentido de heroísmo y romanticismo; véase, esp. idem, op. cit., pp. 17f., 83-88; y 134ff. Es una imagen de Nietzsche elaborada según la interpretación de su hermana Elizabeth, de la cual se sirvieron los Nazis. Véanse, sobre esto: Weaver Santaniello, Nietzsche, God, and the Jews. His Critique of Judeo-Christianity in relation to the Nazi Myth (Albany: State University of New York Press, 1994), pp. 40-41 \& 148-149; Jacob Golomb y Robert S. Wistrich (eds.), Nietzsche Godfather of Fascism? (Princeton \& Oxford: Princeton University Press, 2002), que analiza el papel de Nietzsche desde varias perspectivas.

43 Véase: C. WEBER, Altes Testament u. völkissche Frage, pp. 44-49. 


\section{II.2.2. Identidad: ichtihad e yihad}

Hemos indicado antes que el yihad es parte integral de la fe islámica y su interpretación varía según los grupos, por ejemplo fundamentalistas o progresistas. Reconociendo este conflicto de interpretaciones examinemos su significado pues, al parecer, su colocación dentro del Islam distingue la ideología popular de la fe progresista. En su manual de la ley islámica, Averroes (Abu al-Walid Muhammad Ibn Muhammad Ibn Rushd) que explica las varias posturas adoptadas por los estudiosos musulmanes entiende el yihad como la guerra armada y la considera una obligación común y no individual ${ }^{44}$. Averroes no aboga por el yihad, sino que explica su carácter legal: quiénes tienen la obligación de practicar esta actividad y cuáles son las condiciones admitidas para esta praxis, avanzando una interpretación imparcial de las opiniones de las escuelas jurídicas islámicas. Pero el concepto del yihad islámico no conoce un desarrollo lineal ni unanimidad entre los estudiosos. Es decir, el concepto actual del yihad sería resultado del ichtihad.

Ichtihad según B. S. Himmich, est l'instance par laquelle des pratiques cognitives (le jugement discrétionnaire, le raisonnement analogique ou la décision collective) se manifestent dans l'organisation religieuse des rapports socio-juridiques des musulmanes. Sa signification pour la conscience du croyant c'est qu'il est une pratique théorisante ou une théorie de la pratique. Il a fini par s'identifier à une conception de l'effort. Effort physique ... et effort d'être là par le commentaire et l'interprétation.

L'ijitihâd se situe ainsi dans le prolongement interprétatif du réel. On en use pour tempérer ou actualiser l'existence en rapport à un savoir. En d'autres termes, il est l'expression d'une ingérence humaine dans la loi divine ${ }^{45}$.

Esta concepción del ichtihad busca fundar la actividad histórica-interpretativa en el ámbito teórico o ideológico. Además pone de relieve sus aspectos descriptivos, explicativos y críticos que transforman la praxis. Sería entonces mejor precisar el ichtihad «comme la volonté manifestée par la pensée musulmane pour se conserver, se développer ou se dépasser» ${ }^{46}$.

Himmich, aún cuando la acepta, va más allá de la concepción tradicional; su postura es también compartida por los 'musulmanes progresistas'. Para los

\footnotetext{
44 Jihad in Mediaeval and Modern Islam: The Chapter on Jihad from Averroes' Legal Handbook 'Bidãyat ai-Mudjtahid' and The Treatise 'Koran and Fighting' by the Late Shaykh al-Azhar, Mahmûd Shaltût.Translated and annotated by Rudolph Peters (Leiden: E. J. Brill, 1977), pp. 9-11.

45 B. S. Hiммich, De la formation idéologique en Islam, p. 21.

46 B. S. НIмMICH, De la formation idéologique en Islam, p. 23.
} 
sunitas toda actividad musulmana cae dentro la charia -ley islámica, cuyas fuentes son el Corán-, la sunna (práctica ejemplar atribuida a Mahoma y sus compañeros), la ijmaa (consenso comunitario) y el qiyas (razonamiento analógico). Dentro del último, figura el ichtihad (razón independiente o interpretación crítica entendida como instrumento de la aplicación de la charia). En este sentido el ichtihad se opone al taqlid (imitación o adherencia a la práctica antigua) ${ }^{47}$. El aspecto crítico, individual, innovador, etc. hace el ichtihad atractivo para los reformadores. Entre los estudiosos musulmanes varían las opiniones en relación de la continua validez del ichtihad y a veces, hablan de la puerta al ichtihad cerrada ya desde el siglo noveno. Pero T. Ramadan llama la atención sobre el hecho de que esta perspectiva se refiere solamente a las condiciones válidas para la práctica del ichtihad. El Islam contemporáneo debe reconocer que el ichtihad es la tercera fuente de la charia, incluye ya el qiyas en ello, fue abandonado por razones históricas y es responsabilidad colectiva musulmana. Además: "Al-ichtihad continúa siendo el instrumento más importante concedido a los musulmanes para llevar a cabo la vocación universal del islam [sic], gracias a una dinámica constante de adaptación a la luz de la época y del contexto"48. Desde esta perspectiva, ¿cómo se podría describir el yihad? ¿Cómo este constituye la identidad islámica?

Entendido como lucha armada, el yihad constituye solamente una, aunque importante, dimensión del Islam histórico y contemporáneo. Sin entrar en una discusión detallada sobre este concepto, indiquemos algunas etapas de su recepción y su pertinencia a nuestra temática antes de explicar su significado ideológico-religioso que promete hacer comprender la reacción islámica contra las caricaturas de Mahoma. En la clásica interpretación, el yihad como lucha armada tiene tres objetivos claros: vigorizar el Islam, defender/proteger

47 Entre los instrumentos interpretativos de la ley islámica se reconocen principalmente: el maslaha (interés común), el naskh (abrogación), el taqlid, y el ichtihad. Por una discusión desde la perspectiva del wahabismo, véase: N. J. DELong-BAs, Wahabi Islam, esp. pp. 101-115.

48 T. RAMADAN, El Islam minoritario, p. 135 [= Western Muslims and the Future of Islam (Oxford: Oxford University Press, 2004), p. 48]; véanse también: pp. 147-160 donde el autor ofrece "perspectivas para un «ichtihad» contemporáneo". Aun aceptando la postura tradicional, Ramadan como Himmich considera el ichtihad más que un simple instrumento interpretativo, y afirma su validez y relevancia contemporánea; a diferencia del wahabismo no lo opone a la ley divina: "Ijitihad is, in fact, the rational elaboration of laws either on the basis of the sources or formulated in the light of them. Thus, even ijma (consensus) is the product of a collective human, rational discussion ..." T. Ramadan, Western Muslims and the Future of Islam, p. 45; “... the doors of ijitihad have never been closed; no scholar would have the right to make such a decision in the name of Islam because a declaration such as this is, by its very nature, against Islam. In fact, ijitihad, as the third source of Islamic law and jurisprudence, is fard kifaya, a collective responsibility" ibid, p. 48. 
a los creyentes y erradicar la no-fe ${ }^{49}$. Es una obligación común ${ }^{50}$ y responsable, no emprendida por motivos puramente políticos o como represalia. Aun cuando la llamada al yihad siguió bajo y contra el colonialismo europeo, éste sirvió sólo para incitar y movilizar al pueblo; una lucha armada no hubiera tenido ningún éxito contra el poder ocupante ${ }^{51}$. Quizás por eso, y no por razones ideológicas-religiosas, el Islam bajo el colonialismo desaprobó la lucha armada, p. e. contra el British Raj,,$^{52}$ y en la modernidad buscó interpretar el yihad como bellum justum ${ }^{53}$. Esta interpretación del yihad como guerra justa clasifica la causa belli principalmente en dos categorías (relacionadas con la propagación y defensa del Islam) conforme a la concepción clásica ${ }^{54}$. Mientras esta concepción modernista en su inicio restringió la guerra a sólo defen-

49 "The direct purpose of jihad is the strengthening of Islam, the protection of believers and voiding the earth of unbelief", R. Peters, Islam and Colonialism, p. 10. Para la concepción clásica y los textos coránicos en que se basa, véanse: R. PETERS, Islam and Colonialism, pp. 9-38; para una interpretación moderna de estos textos, véanse: Jihad in Medieval and Modern Islam, pp. 26-79, esp. pp. 39-52, donde Mahmud Shaltut (1893-1963), un estudioso egipcio, explica los versículos coránicos relacionados a la guerra y observa: "there are only three reasons for fighting, viz. to stop aggression, to protect the Mission of Islam and to defend religious freedom" ibid, p. 51; la misma perspectiva se mantiene en el wahabismo aun cuando le pone en el contexto misionero (da'wah): "Ibn Abd al-Wahhab's overwhelming concern was the winning of adherents through faith of the heart - a goal that he believed could best be achieved through dialogue rather than destruction. According to this vision, jihad has no place as an offensive activity. It is a method of last resort in defending the Muslim community from aggression so that the work of proselytization can continue". N. J. Delong-Bas, Wahhabi Islam, p. 225; por una discusión detallada, véase: ibid, pp. 193-225.

50 Existe todavía una obligación individual (fard 'ayn) cuando el yihad se entiende como guerra defensiva o justa según Husain Kassim, Legitimizing Modernity in Islam. Muslim Modus Vivendi and Western Modernity (Lewiston/Queenston/Lampeter: The Edwin Mellen Press, 2005), p. 49; véase también: R. PETERs, Islam and Colonialism, pp. 15, 86, 90, 97 , etc. donde precisa algunos ejemplos.

51 Véase: R. PETERS, Islam and Colonialism, pp. 39-104, que provee varios ejemplos desde India, Egipto, Sudan, etc.

52 Véase: R. Peters, Islam and Colonialism, pp. 50-53. Pero la desaprobación de la lucha armada contra el British Raj no disminuyó sino aumentó la lucha pacífica, la no-cooperación con los colonizadores ideada por M. Gandhi, véase: RAFIQ ZAKARIA, Indian Muslims. Where have they gone wrong? (Mumbai: Bharatiya Vidya Bhavan, 2004) pp. 85-93 que explica también la importancia del movimiento Khilafat (1919-1924) en este contexto.

53 Según H. KASSIM, Legitimizing Modernity, pp. 47-59, debe distinguirse entre "jihãd as just war and jihãd as qitãl, namely war for religion or territorial expansion' (ibid, p. 55); pues la segunda se origina con los juristas clásicos que aplican el concepto dar al-harb al mundo no-islámico haciéndole igual a la esfera caótica, sin paz y orden.

54 Véase: R. PETERS, Islam and Colonialism, esp. pp. 121-135. "Of the first kind are the following causes: 1 . Strengthening monotheism and destroying polytheism and false gods. This is based on the nearly identical verses K 2:193 and K 8:39 ... 2. Protecting the Islamic mission against those who stand in its way. This is also called protecting freedom of religion. ... This cause is also scripturally founded on K 2:193 and K 8:39 ... As for the causes connected with the idea of defence, these are: 1 . Repelling aggression on Moslem lives and pro- 
sa y ofreció interpretaciones contextuales de textos bélicos (p. e. sûra 9: 5, 29, 129 etc.), la reacción fundamentalista propuso una revolución permanente hasta el establecimiento de la charia. En relación del yihad hay que distinguir entre modernistas y fundamentalistas: "The modernists have reacted in a defensive manner, by adopting Western values and reforming their religion in the light of these newly imported ideas. They have transformed Islam into a religion that is well suited for the Westernized elite. The fundamentalists, on the other hand, have reacted in a self-assertive manner, by rejecting everything Western and emphasizing the real Islamic values"55. Aun cuando esta limpia polarización entre modernistas y fundamentalistas no es del todo correcta, pues la sociedad musulmana ha mantenido casi siempre su diversidad, hay que destacar los elementos centrales de la concepción modernista/renovadora compartida también por los fundamentalistas. Estos son el empleo del ichtihad que contextualiza los textos coránicos, el reconocimiento de la libertad religiosa y la voluntad de comprender el yihad más que como una guerra armada. Independientemente de su concepción cronológica o por grupos o movimientos, el yihad ha sido siempre justificado por su carácter religioso; eso se manifiesta especialmente en la universalidad reclamada por los valores islámicos y la interpretación del yihad como ley islámica internacional ${ }^{56}$.

\section{II.2.3. El yihad desde la antropología religiosa}

Desde la perspectiva antropológica-sociológica podría explicarse la transformación de guerra tribal en yihad que confirmaría el aspecto específico religioso. Históricamente se coloca esta transición durante los años inmediatamente después de la hégira en $622 \mathrm{~d}$. C. cuando los seguidores de Mahoma unidos en la comunidad (umma) experimentaron su lealtad tribal desafiada por los abusos y ataques de parte de los habitantes de Meca. Varios niveles de relaciones existían en la umma, entre la umma y los habitantes de Meca, y los habitantes del archipiélago arábigo. Por una parte, se desarrolló una solidaridad alrededor de Mahoma entre los creyentes y simpatizantes que pertenecían a varias tribus y/o religiones. Por otra parte, si la solidaridad ará-

perty in case of an actual or expected attack by enemy forces. This is founded on K 2: 190 ... 2. Preventing oppression and persecution of Moslems outside the Territory of Islam.... It is based upon $\mathrm{K} 4: 75 \ldots 3$. Retaliating a breach of pledge by the enemy. This is supported by K 9:12" R. Peters, Islam and Colonialism, pp. 122-23.

55 R. PETERs, Islam and Colonialism, p. 135.

56 Véase: R. PETERS, Islam and Colonialism, pp. 135-150, donde se da también una bibliografía, esp. nota 74 . 
biga se basó tradicionalmente en lazos de parentela, con el liderazgo religioso de Mahoma y después de las acciones emprendidas contra él por los coraixíes (quray̌s), se fundamentó en lo religioso. Un claro ejemplo por ello se encuentra en los ataques contra los coraixíes (victoria de Badr, 624 A.D.) violando la ley tribal de no saquear a miembros de su propia tribu ${ }^{57}$. Las revelaciones en este contexto (sûra 3 ) testimonian su legitimidad. Así la identidad personal no se define más en referencia a la pertenencia a la tribu, sino a la comunidad (umma). Si esta explicación del origen del yihad es aceptable, debe entenderse como descripción del estado de relaciones entre el mundo islámico y no-islámico. Además el yihad no se refiere principalmente a lucha armada (a pesar de la clásica comprensión ${ }^{58}$ ) sino a relaciones religiosas-ideológicas que definen la persona dándola su identidad. Esto se confirma por el término mismo.

Los estudiosos están de acuerdo en que el significado semántico del término yihad consiste en poner todo el esfuerzo, poder y habilidad contra lo que merece desaprobación por ser enemigo, malicioso o vicioso dentro de uno mismo ${ }^{59}$. En este sentido hay que hablar de actitud y esfuerzo interior que implica el corazón, la lengua, etc. contra el mal en cualquier forma. Desde este sentido amplio el yihad es ascesis, no asesinato (qitãl); precisamente por eso la tradición habla del gran yihad en contraste con el yihad de la espada (jihãd al-sayf), aun cuando en ambos casos la meta consiste en estar por (o restablecer) el camino de Alá. Además el yihad se emplea para resolver los conflictos dentro la comunidad, y así se cualifica como medio de promover el

57 Véase este argumento desarrollado en detalle por Reuven Firestone, Jihad. The Origin of Holy War in Islam (Oxford: Oxford University Press, 1999), esp. pp. 127-134.

58 Para un análisis detallado de la interpretación tradicional y de la necesidad de una nueva lectura sobre el yihad, véase: R. FIRESTONE, Jihad, pp. 47-91; aquí su conclusión: "PreIslamic fighting was nonideological and was conducted either for material gain or to retaliate or exact revenge on unrelated or distant kinship groups. Responsibility to engage in war was a necessary component of kinship responsibility and tribal solidarity. Fighting in the fully developed Islamic system, on the other hand, became a highly ideological issue despite the added benefit of material gain in the form of spoils. Motivation to engage in war moved from economic incentive and kinship commitment to the ideological responsibility of religious commitment, and it created the awkward situation in which New Muslims were commanded to fight against members of their own intimate kinship groups because of their new religious affiliation. Religious affiliation replaced kinship affiliation as the religious community replaced the tribe, but the transition was difficult and... never entirely successful", ibid, p. 91. Como argumenta Juan Vernet, Mahoma (Madrid: Espasa, 2006, pp. 51-2; 64), "el vínculo de la sangre" entre la sociedad beduina empezó a romperse ya con el abandono de Abu Lahab que no abrazó las revelaciones de Mahoma como los demás miembros de su clan.

59 Véanse: R. Peters, Islam and Colonialism, pp. 117-121; R. Firestone, Jihad, pp. 1618. 
bien común, la educación, etc. Aun cuando el yihad para la propagación de la religión ocupa un plano privilegiado, el Corán rechaza la conversión forzada por varias razones: la verdad (religión verdadera) no necesita la fuerza; pues no facilita una fe fiable, etc. El yihad significa entonces el esfuerzo en el camino de Dios. Todo eso lleva a comprender el yihad en manera nueva:

[The] search for solutions and the multidimensional engagement of Muslims with the aim of applying concretely the teachings of the "Path to faithfulness" require a constant and balanced effort, for which Arabic uses the term jihad.The Way, al-Sharia ... is the path toward justice, demands individual and collective efforts, jihads, to be made at various levels and in various areas. On the intimate level, it is working on one's self, mastering one's egoisms and one's own violence; on the social level, it is the struggle for greater justice and against various kinds of discrimination, unemployment, and racism; on the political level, it is the defense of civil responsibilities and rights and the promotion of pluralism, freedom of expression, and the democratic processes; on the economic level, it is action against speculation, monopolies, and neocolonialism; on the cultural level, it is the promotion of the arts and forms of expression that respect the dignity of conscience and human values. These are the $j i$ hads to be carried out in the name of active and responsible citizenship - jihads that are spiritual as well as social, economic, political, and ecological, that reconcile Muslim participants in Western societies with the deep meaning of Islamic terminology. The global understanding of sharia as a Way toward justice opens up the new and demanding horizon of civil jihad ${ }^{60}$.

Esta es la voz del Islam progresista que contrasta radicalmente con la de Bin Laden ${ }^{61}$; es una lectura que busca incorporar el Islam en la sociedad occidental sin rechazar la identidad musulmana. ¿Cómo lee la prensa, especialmente española, las protestas contra las caricaturas de Mahoma?

\section{II.3. La prensa española: religión y libertad de expresión}

$\mathrm{Al}$ introducir el análisis y la perspectiva de la prensa española durante e inmediatamente después de las protestas contra las caricaturas no buscamos evaluar un reportaje sino obtener algunos puntos claves para nuestra temática centrada en los medios de comunicación. El concepto que sobresale en todos los reportajes ha sido el de la libertad de expresión: la publicación y la

60 T. RAMADAN, Western Muslims and the Future of Islam, pp. 113-14; cursiva en el texto.

61 Sobre Bin Laden y su yihad, véanse: N. J. Delong-Bas, Wahabi Islam, pp. 227-279. 
protesta manifiestan, respectivamente, su defensa y uso, y la falta de ella. Mientras casi todos aprecian la libertad de expresión como signo de la democracia occidental ${ }^{62}$, los musulmanes junto a los estudiosos del Islam de un modo especial reclaman respeto a la hora de practicar dicha libertad. Pues, "la libertad de expresión es también respetar a los otros"63, opina Juan Vernet. "Sólo porque tengas el derecho legal de hacer algo, no significa que tengas que hacerlo", añade Tariq Ramadan. Desde esta perspectiva la publicación de las caricaturas ha sido "una manera muy estúpida de usar la libertad de expresión"64. El empleo de la libertad de expresión no debe ser un insulto irracional.

Aun reconociendo el "estúpido mal gusto" en publicar las figurillas, Mario Vargas llosa observa que "los diarios que han corrido el riesgo de reproducir las viñetas son casi todos de centro o de centro derecha" y lamenta que "buena parte del silencio de cierta izquierda ante este asunto se debe a que tiene serias dudas sobre cuál es la opinión políticamente correcta en este caso"65. Implícitamente se reconoce así que las protestas no se limitan a una cuestión legal sino a convivencia social basada en creencias religiosas e ideológicas. Naturalmente toda la prensa trae expresiones de rechazo de la violencia perpetuada y promovida por los manifestantes aun siendo grupos minoritarios ${ }^{66}$. No se ha de olvidar tampoco que había sido una provocación la que inició la protesta; describieron las caricaturas como ofensivas ${ }^{67}$ y su publicación como expresión de arrogancia ${ }^{68}$. ¿Son quizá expresiones de miedo del mundo musulmán o un testimonio de la integración fallida? ${ }^{69}$ Todo esto

62 Véanse, Anwar Ibrahim, "Cultivar las semillas de la democracia”, El País, 11 de abril de 2006, p. 15 , donde el autor indica algunos requisitos para implantar la democracia en el mundo musulmán: "El verdadero cultivo de la democracia exige más que una mera implantación de las elecciones. ... Necesita la garantía de una separación de poderes y la liberación del sistema judicial del dominio de autócratas y tiranos. Por encima de todo, exige la protección de las libertades fundamentales y una prensa libre".

63 "Debate de civilizaciones", El País, martes 7 de febrero de 2006, p. 34. Páginas 3436 traen varias opiniones de musulmanes y no-musulmanes matizando las ideas desde perspectivas políticas, sociológicas, antropológicas, etc.; véanse también: El País, domingo 12 de febrero de 2006, p. 17.

64 "Debate de civilizaciones", El País, p. 34.

65 "El derecho a la irreverencia", El País, domingo 12 de febrero de 2006, pp. 15-16.

66 Véanse, p. e.: $A B C, 6 / 2 / 2006$, p. 35-36, 38; 16/2/2006, p. 34; El Mundo, viernes 17 de febrero de 2006, p. 23.

67 "El Vaticano, Washington y Londres critican la publicación de las caricaturas", $A B C, 4 / 2 / 2006$, p. 39

68 "Las caricatura de la discordia", El País, jueves 9 de febrero de 2006, p. 4; “Ofender a los musulmanes es fruto de la arrogancia de laicos occidentales", El Mundo, jueves 9 de febrero de 2006, p. 27.

69 Véanse, p.e.: $A B C, 9 / 2 / 2006$, p. 36; 12/2/2006, p. 21; Antonio Caño, «La última frontera de Europa », El País, lunes 10 de abril de 2006, pp. 14-15. 
conduce -además de los aspectos ya mencionados- a la cuestión de la legitimidad de la representación religiosa. Aun cuando el aniconismo caracteriza tanto el judaísmo como el Islam, ¿no existían representaciones de Mahoma? "La imagen de Mahoma no es tan tabú", observa Guillermo Altares 70 . Pero pregunta Abduljalil Sajid71: "Nadie, cristiano o musulmán, puede dibujar a Mahoma... ¿lo ha visto alguien?" No abordamos estas cuestiones desde la perspectiva histórica pues son asuntos intrarreligiosos y hermenéuticos; volvemos entonces a abordar la cuestión principal, la libertad de expresión, que nos facilitaría clarificar también estos aspectos colaterales.

¿Cómo se debe entender la libertad de expresión? ¿Fue ésta dañada por la publicación de las caricaturas de Mahoma? ¿Viola el aniconismo la libertad de representar a Dios y sus profetas? El aniconismo es un fenómeno religioso compartido por varias religiones tradicionales e históricas, que voluntariamente (y no por inhabilidad técnica o retraso cultural) rehúsa representar a Dios por razón de su inefabilidad: es decir por la irracionalidad de su trascendente inmanencia o inmanente trascendencia. Esta afirmación antropológica-religiosa considera el aniconismo como una libre opción que hace justicia a Dios y reconoce la inconmensurabilidad del hombre delante del divino. Hablar del aniconismo únicamente como prohibición religiosa -como hacen entre otros los musulmanes radicales- ignora esta dimensión antropológicareligiosa que es el fundamento de tal prohibición y en consecuencia reduce la religiosidad a un puro legalismo; además justifica la actitud iconoclasta como prevención contra la idolatría. Sin embargo, elementos básicos religiosos no se oponen a la representación de Dios, si procedemos desde la interpretación propia de la religiosidad humana. Sería otra opción que, aun reconociendo tanto la inefabilidad divina como la inconmensurabilidad humana, aprecia relacionarse con Dios a través de simbolismos concretos como por ejemplo la representación figurativa.

¿Son entonces aceptables las caricaturas de Mahoma? ¿Son válidos ejemplos de la libertad de expresión? $\mathrm{O}$, ¿cuál es el valor de la libertad de expresión? Reconociendo el "frívolo e irresponsable" modo de la libertad de expresión en la publicación de las caricaturas, Javier Peña opina justamente que "sin libertad de expresión no puede haber una sociedad de ciudadanos libres e iguales. Sólo si podemos manifestar sin represión nuestras convicciones y creencias somos respetados y reconocidos como personas capaces de pensar y de actuar por sí mismas". Sin ella, la pacífica vida social "como iguales en derechos y diferentes en creencias" no sería posible, pues "la alternativa es el

${ }^{70}$ El País: Domingo, 12 de febrero de 2006, pp. 2-4.

$71 A B C, 19 / 2 / 2006$, p. 42. 
monólogo solitario del más fuerte"72. Eso no significa que la libertad de expresión no tenga límites. "La libertad de expresión es una libertad negativa: significa que el poder no puede impedir que te expreses en conciencia. Pero no es una libertad positiva: no significa que estés obligado a ejercerla hasta las últimas consecuencias, por perversas y contraproducentes que sean. ... La libertad de opinión está para criticar al poder y a los poderosos, no para abusar de los débiles sometidos"73. En otras palabras, la libertad de expresión debe defender, garantizar y promover "la propia dignidad del hombre" que es el derecho más elemental al cual debe ser sometida ${ }^{74}$. Si estas perspectivas son válidas ${ }^{75}$, tendremos que concluir que el modo y el tiempo de las publicaciones de las imágenes de Mahoma no fueron legítimas ni favorables al bien común, aun siendo lícitas. Abordar la cuestión sólo desde la perspectiva legal no nos hará comprender el significado de las protestas; debemos entrar, pues, en el complejo campo de la religiosidad. Al parecer fue éste lo que la prensa en general dejó de lado a pesar de su impresionante análisis social, político, filosófico, etc. ${ }^{76} \mathrm{El}$ apartado siguiente tratará la cuestión desde la perspectiva religiosa.

La fe verdadera incita al respeto,

y debe respetar también lo que es sagrado para los demás. ${ }^{\beta}$

72 "El valor de la libertad de expresión", El Norte de Castilla, martes, 14 de febrero $\operatorname{del} 2006$, p. 27.

73 EnRIQue Gil Calvo, “Chistes de moros”, El País, viernes 17 de febrero de 2006, p. 14.

74 Juan Manuel de Prada, "Reírse de Dios", $A B C$, sábado 4/2/2006, p. 5.

75 La prensa española representa también otras perspectivas que enfatiza o reduce la cuestión de la libertad de expresión a sólo un derecho. Véanse, p. e.: JosÉ MARía LASSALLE, "Soy danés", $A B C$, jueves 9/2/2006, p. 7; Javier Martínez-Torron, "El poder de unas caricaturas", $A B C$, martes 14/2/2006, p. 7; Sebastián Serrano, "La excepción religiosa", El País, domingo 12 de febrero de 2006, p. 16; Ayaan Hisri Ali, "Soy una disidente del islam", El País, sábado 18 de febrero de 2006, p. 6; Paolo Flores D'Arcais, "Contra las nuevas santas alianzas", El País, domingo 19 de febrero de 2006, pp. 13 \& 15.

76 Reconozco que una de las importantes funciones de la prensa consiste en establecer la agenda de temas de interés público, descartando los aspectos más profundos, como dejó ver en la controversia acerada A. Schimmel en Alemania; véase: ANNE HofFMANN, Islam in den Medien. Der publizistische Konflikt um Annemarie Schimmel (Münster: LIT Verlag, 2004). Esto no significa que los demás aspectos o perspectivas son menos importantes o irrelevantes, al contrario son con frecuencia necesarios para una comprensión crítica del asunto actual.

${ }^{B}$ Kofi Anan a los Talibanes que en Marzo del 2001 destruyeron la histórica estatua de Buda en el camino de la seda: "True faith elicits respect and you have to respect what is sacred to others". 


\section{Religiosidad, ideología y secularismo}

En las páginas anteriores se buscó demostrar que la clave de bóveda -la libertad de expresión- no se deja colocar exclusivamente en la esfera legal; pues es la piedra angular del edificio humano que se construye en sintonía con varios niveles y sobre todo con la trascendencia. Las protestas contra las caricaturas de Mahoma manifiestan, como hemos visto, la desilusión de los musulmanes con Occidente -desilusión no por no ser tolerados, sino por no ser considerados iguales o por no ser comprendidos. Uno ya puede explicar esta situación sociológica y políticamente. Pero la misma desilusión, esta vez como acusación, sale también de la boca de los autores y editores de las imágenes: los musulmanes buscan apartarse, reclaman un derecho especial para ellos por razón de su religión. Estamos en una situación de tensión cuya causa se atribuye, sin crítica, a la religión en general o la creencia islámica en particular. Valdría la pena preguntar, ¿qué concepto de religión o creencia emplean aquí? ¿Es la religión un consenso intersubjetivo sobre ética, por ejemplo, que se cambia según la opinión publica? $\mathrm{O}$ ¿es la religión la que constituye al hombre? ¿De dónde se sacan los principios para definir por ejemplo la libertad de expresión? En breve, sin una referencia común valida tanto para los musulmanes o/y creyentes como para los ateos o/y no-creyentes sería difícil resolver la cuestión de la libertad de expresión y su fundamento, la dignidad de la persona. Busquemos entonces proponer una concepción antropológica religiosa que puede servir como religiosidad compartida, y desde ahí diferenciar las varias perspectivas que valoran la situación conflictiva actual.

\section{III.1. La religiosidad humana}

Es frecuente referirse a las religiones de la humanidad como religiones primitivas, religiones sin escritura, religiones arcaicas, religiones preagrícolas, etc. que hoy se llaman generalmente religiones tradicionales o autóctonas. Cualquier que sea el apelativo empleado no hay duda que estas fueron las religiones que la humanidad practicó durante el $95 \%$ del tiempo de su existencia terrena; las actuales religiones, llamadas históricas, cubren solamente el $5 \%$ de la existencia humana. A pesar de este hecho, Karl Jaspers argumentó que por la transformación religiosa ocurrida entre 800-200 a. C., las grandes religiones de la humanidad manifiestan un mejor conocimiento del hombre, y las religiones tradicionales tienden a desaparecer ${ }^{77}$. Pues la trascendencia, re-

77 Jaspers avanzó su tesis en su libro: Vom Ursprung und Ziel der Geschichte (München: R. Piper \& Co. Verlag, 1950 [1949]), esp. págs. 17-21; John Hick que adoptó su tesis, 
velación e historicidad reclamada por las grandes religiones les facilitan conocer y reconocer el mundo, al hombre y su prójimo de una manera hasta entonces imposible. Se ha descubierto que la actual existencia terrena carece de la plenitud posible garantizada a la humanidad por su creador. La responsabilidad interhumana, en relación con el mundo y con la trascendencia no se basa simplemente en visiones o ideologías cosmológicas, sino en la irrupción de la divinidad en la historia que continúa progresando definitivamente hacia el telos adecuado a la persona humana. ¿Se puede entonces pretender que los valores representados por las religiones tradicionales están ya superados? Examinémoslos en breve empleando un relato que proviene de Mozambique.

Uno de los mitos autóctonos problematiza las relaciones interhumanas de la manera siguiente:

$\mathrm{Al}$ apuntar el sol el hombre salió a pescar; él estuvo pescando todo el día, llenó sus cestos de pescado; al caer el sol, recogió el fruto de su trabajo y marchó en dirección a su casa. Como el camino pasaba por la selva, se encontró con un cocodrilo que le saludó amigablemente. Pero el hombre no respondió al saludo; el cocodrilo se sintió entonces ofendido y se quejó ante el juez de la ruda conducta del hombre. Al ser llamado por el juez, que le ordenó explicar su conducta ofensiva, el pescador dijo: "cuando me encontré con el cocodrilo, llevaba sólo tres cestos de pescado; uno estaba destinado a mis hijos, otro a mis padres y el último a mis mujeres. No me quedaba nada que ofrecer al cocodrilo; y por eso, no le he respondido". Al escuchar esta respuesta, el juez le dio razón; y el cocodrilo concordó con la sentencia.

Como todos los mitos, este también necesita interpretación para mejor comprender su significado. Según los autóctonos, se refiere a la responsabilidad o la interrelacionalidad entre las tres generaciones: del pasado, presente y del futuro representada por los padres, mujeres e hijos respectivamente. Además existe una distinción entre el mundo humano (cultural) y de los animales (natural). Conocer y reconocer esta distinción se manifiesta en la prioridad atribuida a su propio mundo cuyos lazos son los de la parentela. En una situación de crisis o de tensión (se trata de la comida -pescado- buscada y querida igualmente por el pescador y el cocodrilo) el pescador supo comportarse como miembro del mundo humano y demostró su responsabilidad.

matiza las características de las religiones arcaicas como inmanencia, conservación, armonía, etc.; véase: An Interpretation of Religion (New Haven: Yale University Press, 1989), esp., pp. 21-35. 
Aun cuando esta interpretación admite que el mito busca conservar más que cambiar la estructura social, queda obvio el reconocimiento de interdependencia tanto entre los mundos culturales y naturales como entre las generaciones humanas. El hombre concebido como 'agente/actor' no debe rehuir la propia responsabilidad, sino realizarla precisamente reconociendo su dependencia. Responsabilidad hacia y dependencia de la generación de los antepasados (que para la religión tradicional incluye la divinidad) constituye una dimensión importante de ser humano. No existen relaciones y responsabilidades si no son recíprocas; son valores y afirmaciones ya compartidos por las grandes religiones. Basta indicar, entonces, que la tesis de la transformación axial avanzada por $\mathrm{K}$. Jaspers no aniquila sino confirma los valores tradicionales. Pues estos constituyen al hombre en relación de la manera en que las religiones hoy los fundan o defienden. El concepto de la religiosidad que empleamos representa estos valores antropológicos -como la responsabilidad recíproca-, imprescindibles para vivir como personas humanas.

Desde la antropología religiosa, las religiones tradicionales conciben una triple relacionalidad (inconmensurabilidad, dialéctica y diálogo) como básica en la religiosidad humana expresada en categorías temporales como presente, pasado y futuro. La persona que interioriza esta religiosidad en relación con su tribu/sociedad se deja formar como miembro de este grupo o mejor dicho llega a ser hombre. El anthropos es aquel que actúa según dichas relaciones que, aunque recíprocas, son asimétricas, especialmente en los ejes del pasado y del futuro, indicando la mayor responsabilidad de la persona humana. Así el pescador, representante de la generación presente, tiene una mayor responsabilidad hacia sus hijos que representan la generación futura, y al mismo tiempo reconoce con gratitud su existencia recibida gratuitamente de los antepasados. Como mencioné antes, este mundo de los antepasados, que incluye las divinidades, deja este mundo (natural) al hombre para que él lo administre, transformándolo en cosmos -el mundo (cultural) ordenado donde se puede vivir mejor. Definir la propia existencia a través de las relaciones mencionadas nos sitúa en este mundo ${ }^{78}$. La religiosidad elemental a la que nos referimos es entonces co-término con nuestra condición de ser hombre. Cada religión particular (tradicional y/o histórica) interpreta y matiza esta base antropológica de relaciones consigo mismo, con el otro y el Otro. Esta interrelacionalidad constituye la base de la responsabilidad humana; sin ella no se puede concebir la libertad de expresión. En otras palabras, la libertad de expresión conlleva la responsabilidad recíproca que en todas las situacio-

78 Para una discusión de los aspectos mencionados, véase mi ensayo: "El desafío misionero hoy", Estudio Agustiniano, 36 (2001) 281-330, esp. 298-316. 
nes son asimétricas, dialécticas y dialogales. Para comprender la especificidad de la responsabilidad recíproca se debe tomar la propia religión en perspectiva. Pues las distorsiones históricas podrían haber ocultado la verdadera religiosidad, reduciéndola a una relacionalidad unidimensional sea trascendental o inmanente. Por eso el buscar la religiosidad que constituye al hombre, nos obliga a cuestionar, interpretar y re-vivir la propia fe. Esto lo intentamos siguiendo el Islam progresista.

\section{III.2 : Aggiornamento religioso}

Que el Islam no es una religión monolítica, ni asfixiada en sus creencias y prácticas, sino capaz de adaptarse a la diversidad de tiempos y lugares que abracen su mensaje lo testimonia tanto su historia como su presencia en todos los continentes ${ }^{79}$. No fue cambiando su fe en Dios único y su mensajero Mahoma, sino manifestando la centralidad y universalidad de esta fe en situaciones diversas de la humanidad, como el Islam llegó a ser hoy una de las religiones más seguidas actualmente. El principio de actualización de la creencia islámica consiste -como hemos indicado antes-en el ichtihad, cuyo núcleo es el yihad. Empleando este mismo principio, los musulmanes occidentales ofrecen una interpretación contemporánea de su creencia, que al parecer les ayuda a revivir la religiosidad antropológica en su totalidad. Desde esta perspectiva tendrá la libertad de expresión un sentido diferente que según nuestra opinión se contrapone a la ideología popular fácilmente manipulada por fines políticos e integristas. ¿Cuál es esta visión del Islam?

Según T. Ramadan esta visión del Islam consiste antes de nada en reafirmar la fe en la unidad de Dios (tawhid) en sus tres dimensiones centrales: Dios es uno, el universo creado revela este Dios, y 'la necesidad de Él' constituye la esencia del hombre. Esta expresión del tawhid afirma una concepción de la humanidad específica del Islam, pues la naturaleza del hombre se concibe como reflejo a contrario de Dios. El Islam no propone una visión ni monista ni dualista del mundo, sino distingue entre el creador y el creado proponiendo un dinamismo que conduce a la unión armoniosa. Pues todo hombre

79 Un claro ejemplo en este contexto ofrece el concepto de la justicia, véase: MAJID KHADDURI, The Islamic Conception of Justice (Baltimore \& London: The John Hopkins University Press, 1984); para una descripción detallada del Islam entre otras religiones, véase: Carlo Caldarola (eds.), Religions and Societies: Asia and the Middle East (Berlin: Mouton Publishers, 1982); para un análisis desde la perspectiva cultural, véase: R. MiCHAEL FeEnER (ed.), Islam in World Cultures. Comparative Perspectives (Santa Barbara: ABCCLIO, 2004). 
nace con la fitra en su corazón que le habilita para testimoniar a Dios: “... in the heart and consciousness of each individual there exists an essential and profound intuitive awareness and recognition of the presence of the Transcendent. Just as the sun, the clouds, the winds, the birds, and all the animals express their natural submission ... the human being has within it an almost instinctive longing for a dimension that is "beyond." This is the idea of the fitra..."80. Este testimonio original ha marcado al hombre de tal manera que la religiosidad -la relacionalidad con la Trascendencia, que simbólicamente se concibe como alianza- es parte integral de la estructura de la conciencia humana. Naturalmente necesita esta memoria de fe-de la presencia de Dios en la interioridad-, confirmación y reforzamiento a través de la razón. Para ello el Islam ofrece dos vías: el libro abierto y accesible a todos, el universo, y la palabra revelada de Dios en el Corán que corrige y confirma las anteriores revelaciones. Dentro de esta estructura de referencia islámica, dos puntos son claves: al conocimiento de sí mismo como hombre relacional se llega solamente volviendo a sí mismo; además uno se conoce en su absoluta inocencia reconociendo al Uno que le hace libre. El anthropos -representado por la totalidad de corazón y mente- se constituye enteramente inocente y libre sólo por la fitra: la necesidad de la trascendencia implantada en él. Por eso la primera responsabilidad del hombre consiste en cumplir esta necesidad de Él81. Aniquilarla o negarla equivaldría a arrogancia. El hombre (musulmán) se caracteriza desde su primerísimo inicio como persona humilde y responsable, o diríamos (desde la antropología religiosa) como persona relacional que reconoce la triple relación constitutiva de inconmensurabilidad, dialéctica y diálogo. Todo esto implica la chahada, la profesión de fe, en que se fundamenta la praxis islámica, la charia $^{82}$, que necesariamente requiere la inteligencia humana para interpretar las fuentes. Esto constituye la estructura referencial básica para el Islam. Musulmán sería entonces aquella persona que reconoce la fe en el Uno y se pone en el camino de fidelidad empleando tanto su corazón como su mente en este mundo. El esfuerzo de mantenerse musulmán (que equivale mantenerse en el camino) tendrá éxito sólo volviendo a la fe inicial

80 T. RAMADAN, Western Muslims and the Future of Islam, esp. pp. 11-14.

81 Ramadan emplea la expresión "the need of Him" (Western Muslims and the Future of Islam, p. 18), que, en conjunto, con su explicación de la fe en Dios, se aproxima al concepto "the needful need" empleado por Karl Barth (Church Dogmatics, I/2, p. 318); este aspecto sería útil para comprender el secularismo visto por los creyentes, véase más adelante.

82 Naturalmente Ramadan está proponiendo una nueva interpretación del Islam que busca ir más allá del convencional concepto familiar tanto a los creyentes como a los observadores. No entramos en detalles de esta interpretación, sino que recogemos las ideas útiles a nuestra temática. 
$(\text { fitra })^{83}$ pero simultáneamente interpretándola para la práctica concreta, por ejemplo, en Occidente. Visto así, el musulmán es una persona en continua yihad: en esfuerzo constante y adecuado para estar en el camino de $\operatorname{Dios}^{84}$.

¿A dónde nos lleva esta concepción del hombre religioso? ¿Qué consecuencias tiene en relación con la libertad de expresión? Según esta visión contemporánea del Islam, se debe reconocer que la clásica concepción en relación de dar al-Islam (morada de Islam), dar al-harb (morada de guerra), dar al-ahd (morada de tratado), etc. es inadecuada, y no refleja la realidad islámica en Occidente, ni promueve la convivencia en la sociedad. Sería necesaria entonces representar la situación de los musulmanes por un concepto que reconozca su identidad y refleje su pertenencia a la sociedad occidental. Este concepto puede ser dar al-shahada o alam al-shahada (espacio de testimonio), pues permite relacionar la identidad islámica con su responsabilidad social; además, la expresa en correspondencia con la fe islámica en Dios, destacando especialmente su llamada a testimoniar esta fe en su entorno tanto en palabras como en la acción ${ }^{85}$. Yendo más lejos, este concepto describe en general la tarea musulmana en el mundo entero, dentro la humanidad. Se transforman así desde de una postura de oposición al mundo de no-fe (dar al-kufr), en una de colaboración, contribución y responsabilidad poniéndose en el mundo como testimonio. En consecuencia, ni las religiones ni las culturas se

83 El concepto de la fitra empleado aquí destaca la naturaleza humana como creación inicial y penetrada por la religiosidad -es decir por la necesidad de Él. El versículo del Corán (30:30) en el que se apoya esta interpretación, pone claro énfasis en el monoteísmo. Para una discusión detallada, véase: THOMAS MoOREN, Macht und Einsamkeit Gottes (Würzburg: Echter / Altenberge: Oros Verlag, 1991), esp. pp. 32-33, donde se encuentra también más bibliografía. Agradezco al colega Thomas por su crítica y discusión. Hasta qué punto, pues, se debe/puede hablar de 'fe inicial' es ciertamente una cuestión de interpretación. En este artículo buscamos presentarlo, siguiendo a Ramadan, en un contexto de antropología religiosa, mejor dicho de fe antropológica. La interpretación que este artículo ofrece sigue la orientación dada por Karl Rahner en la obra Grundkurs des Glaubens, esp. pp. 126-132, y por los conceptos de condición humana pre-reflexiva o non-temática. El vacío trascendental existe en la naturaleza humana, pues Dios lo creó para comunicarse Él mismo con el hombre.

84 "a constant and balanced effort", T. Ramadan, Western Muslims and the Future of Islam, p. 113. En las páginas anteriores Ramadan desarrolla la identidad islámica como dinámica, no estática o fija por siempre; véanse, esp. pp. 77-85.

85 [The concept of shahada] "allows the identity and social responsibility of Muslims to be both expressed and linked." "... it recalls the permanent relation to God (al-rabbaniy$y a$ ) and expresses the duty of the Muslim to live among people and to bear witness, in both action and word, to the content of the message of Islam before all humankind. And this is to happen in any society, for it is the basis of our relations with others." T. Ramadan, Western Muslims and the Future of Islam, pp. 75 \& 76 (cursivas en texto original). Para su análisis detallado, véase: ibíd, pp. 65-77; también: T. RAMADAN, El Islam minoritario, pp. 163207. 
oponen, sino que surge una espiritualidad que se siente desafiada por un mundo de ideología, neutralidad o/y secularización. Para afirmarse como musulmán occidental debe reconocer sus logros y fallos -mejor dicho las limitaciones, que comprometen la vida de testimonio. Según el análisis de Ramadan la falta de auto-crítica es uno de los impedimentos a superar ${ }^{86}$; ¿llaman las caricaturas la atención sobre esta y similares facetas de existencia intersujetiva?

\section{III.3. Identidad religiosa, pluralismo y secularismo}

Indicamos que la protesta contra las caricaturas no se deja comprender bien sino desde la perspectiva religiosa musulmana y antropológica. Desde la perspectiva puramente ideológica, legal y/o secular las protestas parecen con razón como un desafío a la libertad de expresión, que naturalmente tiene su límite (como ya he explicado antes) en el bien común, respeto del otro, etc. La cuestión fundamental tanto para los musulmanes como para los demás es otra: ¿cómo o/y por qué la libertad de expresión es tan básica? ¿De dónde surge? La respuesta indicada antes sugiere que esta libertad se funda en la religiosidad elemental humana compartida por todos e implícita en toda persona. La expresión de esta religiosidad en el Islam comienza con la fe inicial ( fitra) que facilita la formación de una identidad religiosa. Si la identidad religiosa aspirada y/o adquirida no se orienta hacia la fe inicial -es decir en otras palabras, no expresa la espiritualidad auténtica y musulmana- no servirá para fomentar la libertad de expresión. Necesitamos entonces examinar la identidad religiosa musulmana propuesta en Occidente. Esto nos conduciría a revisar la actual imagen del Islam tanto para sus adherentes como para sus observadores-participantes.

Según la nueva visión del Islam avanzada por Ramadan, la identidad musulmana consiste en cuatro pilares básicos con dimensiones específicas (representadas por cuatro círculos concéntricos) ${ }^{87}$. Una expresión concreta

86 "To look critically and constructively at the action of one's brother in religion or one's community is a requirement of faith, and self-criticism serves the interest, and above all the dignity, of those who attempt it without complacency or exaggeration. It is this critical and self-critical awareness - and its daring to express itself - that is largely lacking in Western Muslim communities", R. Ramadan, Western Muslims and the Future of Islam, p. 108; para su análisis completa, véase, ibid, pp. 102-112; también: T. RAMADAN, El Islam minoritario, pp. 209-251.

87 Véase: R. RAMADAN, Western Muslims and the Future of Islam, p. 83. Los cuatro círculos constan de: fe, práctica y espiritualidad; comprensión de los textos y del contexto; educación y transmisión; acción y participación; para su detallado análisis, véase: T. RAMADAN, El Islam minoritario, pp. 255-307. 
de esta identidad se manifiesta en la espiritualidad musulmana, que es una vuelta a sí mismo y simultáneamente la auto-liberación cuya figura ejemplar es Mahoma. "The heart of the message of Islam is that a living spirituality comes at the price of willingly making the effort to come back to what is essential, to contemplate the world and to take the road back toward one's self. In the daily practice, along side the "book," the Creator has given human beings a model in the person of the Prophet."88 La expresión de la libertad en cualquiera de sus formas no se obtiene sin este aspecto relacional -la necesidad de Él que nos hace libres. La simple consecuencia de este reconocimiento es múltiple: nos obliga a estar atentos a los aspectos (moral y/o éticamente) "neutrales" de nuestra vida; a reconocer la propia fragilidad, a examinar constantemente el esfuerzo que se pone en 'estar en camino'. Sorprendentemente esta perspectiva tiene mucho que ver con los tres aspectos -integración, ilustración y progreso- criticados por Hirsi Ali ${ }^{89}$ entre los musulmanes occidentales.

Según H. Ali los musulmanes rehúsan integrarse en la sociedad occidental en la que se encuentren especialmente por su concepción de Occidente como el 'otro', el mundo al revés, de los valores no-islámicos ${ }^{90}$. Esta afirmación -compartida también por otros aunque no en todos sus aspectos-implica varios elementos; examinémoslos en breve. La emigración a Occidente es un nuevo fenómeno del siglo $\mathrm{XX}^{91}$, resultado de varios factores: búsqueda de una vida mejor; fuga de las dictaduras y/o de la represión política, cultural, y/o religiosa; reconstrucción tras una guerra; reunión familiar; etc. que están marcados fuertemente también por el colonialismo. Esta diversidad de los primeros emigrantes manifiesta varios niveles de 'integración' en la sociedad occidental. Es cierto que por razones económicas y culturales, los musulmanes como los demás emigrantes se juntaron creando barrios, por ejemplo, exclusivamente de iraníes, pakistaníes, somalíes, etc. que promovían la implantación de la comunidad originaria de su propio país y de su religiosidad. La diversi-

88 T. Ramadan, Western Muslims and the Future of Islam, p. 122.

${ }^{89}$ Véase antes, esp. nota 20 . En las páginas siguientes buscaremos responder en lo posible a las críticas de $\mathrm{H}$. Ali, examinando especialmente su pertenencia a nuestra temática e incluyendo las opiniones de otros críticos y/o observadores del Islam.

90 Véase, p.e., su ensayo "Normas incompatibles. Sobre la integración como iniciación en la modernidad”, en: A. H. Ali, Yo acuso, pp. 44-73.

91 No contestamos la presencia islámica en Occidente ya desde el siglo octavo, pero su presencia contemporánea tiene una naturaleza nueva: emigración y conversión han producido comunidades islámicas de ciudadanos occidentales. La integración a la que nos referimos concierne a estos ciudadanos. Véase:T. RAMADAN, "El Islam de Europa sale del aislamiento" (publicado en: Le Monde Diplomatique, abril de 1998), en: T. Ramadan, El Islam minoritario, pp. 325-331. 
dad religiosa entre los emigrantes y los autóctonos no facilitó la integración; tampoco el estado de minoría islámica en países cristianos. Pero, ¿cuál es o fue la causa de su autoconcepción como comunidad musulmana en oposición contra la 'otra' sociedad occidental? Según H. Ali, es la ideología islámica o "la mentalidad tribal". Ramadan al contrario busca demostrar que la integración falla o ha fallado por falta de definir la propia identidad desde una perspectiva auténticamente islámica, que rechazaría la exaltación de la 'diferencia' contra los otros o la reclusión desde el mundo actual. Pues van contra la espiritualidad islámica. Mejorar la situación de no-integración necesita una revisión en varios aspectos de la creencia y práctica islámicas, a través de educación que tiene tres objetivos concretos: educación del corazón, de la mente y para la autonomía personal ${ }^{92}$. Mientras las caricaturas proyectan una imagen del Islam irracional sin reconocer los desafíos de la integración, las protestas contra ellas buscan legitimar la identidad musulmana basándose en una compresión de un mundo superado (dar al-islam y dar al-harb - nosotros contra ellos). Si la imitación formalista de modelos de otros tiempos en la actualidad traiciona los principios mismos sólo nos queda una solución: la renovación crítica.

¿Necesita el Islam una Ilustración? O quizás ¿es el Islam capaz de renovarse? Ambas preguntas son actuales y se plantean con frecuencia, pero ¿demuestran un conocimiento del Islam o ignoran su historia y la complejidad de la situación contemporánea?93 Ya notamos antes que la integración plena en la sociedad occidental requiere una revisión de la auto-concepción islámica; es la postura representada por la rama 'progresista' fiel a la tradición que no solamente no admite el cierre definitivo del ichtihad ${ }^{94}$, sino que también avanza perspectivas sólidas para fomentar la participación social y política. Según T. Ramadan la participación plena en la política y la sociedad antes de nada debe clarificar la confusión actual, para reconocer y precisar el mensaje social

\footnotetext{
92 Véase: T. RAMADAN, Western Muslims and the Future of Islam, pp. 126-143; aquí, p. 129.

93 Por una descripción introductiva con referencias al mundo contemporáneo, véase: Malek Chebel, L'islam et la raison: le combat des idées (Paris: Perrin, 2005), esp. pp. 118127.

94 Según la postura 'conservadora' el califa Al-Qader (+1031) cerró el ichtihad; pero opinan los reformistas que nunca fue abandonada. Al reformador Rachid Ridha $(+1935)$ atribuyen las siguientes palabras: «Les musulmans ne réussiront à faire renaître la vie morale et culturelle de l'Islam [...] qu'à condition de recourir à l'ijitihad [...] et de procéder ainsi à une nouvelle interprétation de la Loi, naturellement plus souple. [...] C'est pour avoir négligé l'ijitihad que certains d'entre eux sont retombés dans le bédouisme [...] ou dans un état voisin, et que d'autres sont allés s'égarer dans l'hérésie et l'athéisme», citado en: M. Chebel, L'islam et la raison, p. 135; véase también: Ibíd., pp. 130-141 \& 145-151.
} 
del Islam y finalmente actuar en sintonía con la estructura referencial islámi$\mathrm{ca}^{95}$. Dado que en el Islam no existe una confusión (por principios o método) entre los aspectos religiosos, sociales y políticos, prevalece el ichtihad en los últimos dos que se distinguen del primero. La razón de la distinción se basa en la referencia común a todos: en el aspecto religioso se expresa la dependencia en Dios mientras en los demás se expresan la independencia y libertad en relación con los hombres. En consecuencia la ética musulmana está inspirada por la religiosidad islámica como las demás por las suyas; el requerir una separación desde esta fuente inspiradora y normativa aniquilaría el fundamento de la propia identidad. Al parecer el secularismo aboga por esta separación creando con ello un problema serio para todos los creyentes (véanse más adelante). Otra confusión atribuida al Islam concierne su auto-concepción como 'comunidad de fe' (umma) ${ }^{96}$. Según la interpretación progresista el principio de lealtad debe distinguirse entre las varias pertenencias posibles. Mientras la pertenencia a la comunidad de fe marca la espiritualidad, práctica y solidaridad de cada persona, no debe considerarla como una postura apasionada, chauvinista y ciega. Es decir, comunidad de fe se opone radicalmente a toda forma o aspiración comunitarista. Desde esta perspectiva, la promulgación de las caricaturas fue victima de la primera confusión, mientras las protestas lo fueron de la segunda. Tanto los musulmanes como los occidentales carecen de perspectiva crítica y conocimiento mutuo especialmente sobre su mensaje social y referencia básica para la participación política ${ }^{97}$.

Al individuar estos defectos de convivencia social y política entre los musulmanes y los occidentales sólo hemos rozado el núcleo problemático que constituye la compleja cuestión de la religiosidad. En su dura crítica de los musulmanes occidentales y de los "relativistas culturales", Hirsi Ali cuestionó todo valor propio de las religiones a no ser como "fuente de consuelo"98. Hay que recordar que como ella y con ella un ramo influyente de críticos del Islam se define ateo o se inclina hacia estructuras sociales y políticas fundamentadas sólo en un consenso democrático ${ }^{99}$. Dos asuntos son de especial impor-

95 Destacamos sólo algunas ideas propuestas en este contexto; véase: T. RAMADAN, Western Muslims and the Future of Islam, pp. 144-175.

96 Se confirma esta confusión en la perspectiva de A. Hirsi Ali, Yo acuso, p. 51: "La identidad islámica (ser humano-imagen del mundo) es una identidad de grupo y en ella ocupa un lugar fundamental el honor y la ignominia o la vergüenza"; véase también pp. 54 y s. Precisamente la superación de esta mentalidad tribal ha sido el logro de Mahoma.

97 Serge Lafitte («Le choc des caricatures, piège du désordre mondial», en : Développement et civilisations, no. 343 mai 2006, 1-4), tiene razón al escribir: «Il est urgent, de part et d'autre, d'abattre les murs de préjugés et d'ignorance entre les «cultures» », p. 4.

98 Véase: A. Hirsi Ali, Yo acuso, aquí pp. 11;24; 45.

99 A. Hirsi Ali, Yo acuso, pp. 74-83. 
tancia aquí: ¿cuál es el fundamento de la ética social y política? ¿Debe facilitar el pluralismo de valores representados por las varias culturas, ideologías y religiones? Y en ese caso, ¿cómo? En realidad aquí nos encontramos con una verdadera aporía al menos por dos razones: en primer lugar, se entiende la religión y la religiosidad en sentido reducido, llamado frecuentemente científico que reconoce su valor intersubjetivo y su concepción inmanente, pero rechaza la trascendencia reconocida por los creyentes; en segundo lugar, falta un criterio aceptable para hablar del pluralismo de valores. Una vía de salida, mencionada antes, es la de la antropología religiosa:Toda religiosidad -sea inmanencia trascendente representada por las religiones tradicionales, sea trascendencia inmanente reconocida por las grandes religiones- atribuye la normatividad de la ética humana a algo más allá del simple consenso intersubjetivo. Pues la experiencia humana -la memoria histórica- admite que el ego sólo llega a comprender su propia existencia y valor cuando reconoce la primordial presencia del O/otro. La inconmensurable relacionalidad se constituye así en la condición ontológica para toda ética (E. Levinas). Desde la perspectiva religiosa ésta sería la fe inicial: la fuente y el criterio de toda normatividad y libertad individual. Todas las creencias, ideologías y culturas que facilitan la realización de esta condición hacen al hombre responsable.

La afirmación de la relacionalidad básica del hombre no implica su expresión homogénea en las religiones/culturas ni su realización adecuada en las esferas de la política o convivencia social. Si en último análisis el pluralismo religioso se legitima por la libertad individual (en adherirse a las manifestaciones distintas e históricas de Dios), su actualización depende, por ejemplo, de la interpretación preferida de textos sagrados por los creyentes. En el caso del Islam, T. Ramadan nos advierte que el 'tipo de la lectura' determina si uno está abierto o no hacia otras perspectivas y/o creencias ${ }^{100}$. Un ejemplo concreto es la protesta contra las caricaturas, donde la ideología popular se

100 Véase: T. RAMADAN, Western Muslims and the Future of Islam, pp. 200-213, donde el autor trata el dialogo interreligioso como expresión y confirmación del pluralismo religioso. Debe admitir que el Islam tendrá la bienvenida en la sociedad occidental sólo cuando no se deje representar por el pensamiento totalitario: "Erst wenn die Wortführer der Muslime, die im Interesse der Islam-Ideologie in ihren Äußerungen nur auf einen schmalen Asusschnitt ihres Erbes Bezug nehmen, sich wieder dessen Mannigfaltigkeit eingestehen und damit die Geschichtlichkeit dessen, was sie für übergeschichtlich ausgeben, bejahen, werden sie geachtete -und nicht nur gefürchtete- Glieder in der Gemeinschaft der Kulturen der Welt geworden sein." Thomas Nagel, "Die muslimische Glaubensgemeinschaft als die Verwirklichung des göttlichen Willens auf Erden", en: Reinhard Gregor Kratz y Hermann Spieckermann (ed.), Götterbilder-Gottesbilder-Weltbilder. Polytheismus und Monotheismus in der Welt der Antike. Band II: Griechenland und Rom, Judentum, Christentum und Islam (Tübingen: Mohr Siebeck, 2006), p. 240. 
ató con una lectura literal y cerrada. Este podría ser también el caso si el Islam se queda obsesionado con el sexo, pues estará convirtiendo la religión en una "jaula de las vírgenes" como cree Hirsi Ali101. A pesar de la igualdad de las personas, garantizada y promovida por el Corán ${ }^{102}$, en la práctica quedan las mujeres bajo la "desconfianza y la violencia" a causa "de la obsesión por la virginidad". Aun tomando esta afirmación cum grano salis parece que valen las siguientes observaciones que quizás nos dejen comprender la significación popular de las caricaturas de Mahoma: vulneran aquellos lugares precisamente débiles y necesitados de reforma.

La única esperanza verdadera para los musulmanes reside en que practiquen la autocrítica y que pongan a prueba los valores morales recogidos en el Corán. Así podrán romper la jaula en la que están encerradas sus mujeres, y por añadidura, ellos mismos. [...] Pero lo que la cultura musulmana necesita son libros, telenovelas, poesía y canciones que muestran qué ocurre en realidad y que sepan burlarse de los preceptos religiosos,... La burla es una necesidad amarga, pero debe darse ${ }^{103}$.

Ya desde su inicio el Islam promueve una postura en relación a la risa, a los chistes y burlas: prohíbe todo lo que aproxima al ridículo ${ }^{104}$. Aquí se encuentra la orientación y la crítica para una praxis mutuamente respetuosa: "Reconforta con vino tu naturaleza agobiada por las preocupaciones, y compártela con algo de humor, pero solamente lo justo y necesario, del mismo modo que se sazonan los alimentos con sal"105.

\section{Conclusión}

En el curso de este ensayo hemos defendido que las protestas contra las caricaturas de Mahoma no manifiestan tanto un rechazo de la libertad de ex-

101 A. HiRsi ALI, Yo acuso, pp. 95-117: "La jaula de las vírgenes"; véase también: pp. 176-188: "La necesidad de reflexión y autocrítica en el islam"; Claude Liauzu, Empire du mal contre grand satan. Treize siècles de cultures de guerre entre l'islam et l'Occident (Paris: Armand Colin, 2005), pp. 243-251.

102 Véase, T. RAMADAN, Western Muslims and the Future of Islam, pp. 138-143.

103 A. Hirsi Ali, Yo acuso, pp. 110 y 116.

104 Sobre la entera cuestión, véase: LuDwig AmmanN, Vorbild und Vernunft: Die Regelung von Lachen und Scherzen im mittelalterlichen Islam (Hildesheim: Georg Olms Verlag, 1993).

105 "Schaffe deiner von Sorgen ermatteten Natur zur Erholung mit Wein und zerstreue sie mit etwas Scherz; doch gib ihr davon (nur) soviel, wie man Salz zur Speise gibt", Al-Gahiz, citado en: L. Ammann, Vorbild und Vernunft, p. 266; véase también: Al-Gahiz, Le Kitãb Al-Tarbî wa-l-Tadwîr d'al-Gahiz (traduction française par Maurice Adad. -Leiden: E.J. Brill, 1968), p. 180, parafo 123. 
presión como una desilusión contra una malentendida religiosidad, una fallida política de integración, y una angustiosa búsqueda por parte de la minoría musulmana de una reafirmación de su identidad en la sociedad occidental que se define mayormente a través de valores no religiosos y posmetafísicos. Sin aceptar la violenta expresión de estos sentimientos y la manipulación política totalitaria, se han de individualizar en esta crisis al menos tres aspectos centrales: la auto-concepción y la hetero-interpretación del Islam; la definición y constitución de la sociedad por valores seculares; y el papel de la religión en el Occidente contemporáneo. Esperanzador es el intento real de "un islam europeo" que busca redefinir la figura de los musulmanes contextualizando el Corán, reconociendo al profeta como persona histórica y situando a los creyentes en el ámbito cultural occidental. Ya que este esfuerzo está aún en su infancia, debe afrontar críticas, sufrir revisiones y contar con posturas desafiantes integristas. Entonces van a servir tanto la sociedad secular como la religiosidad cristiana en que se basa el llamado derecho a la libre expresión.

El diálogo entre Habermas y Ratzinger hace ver que entre la sociedad secular y la religión deben existir independencia y complementariedad. A pesar de que la religión es innecesaria para legitimar los valores de la sociedad demócrata, tanto la religión como la razón padecen patologías ${ }^{106}$. Entonces se debe promover la co-relacionalidad entre razón y fe. En otras palabras, debe existir un proceso de aprendizaje para que se puedan purificar y sanarse mutuamente. Lo que impide dicha relacionalidad mutua son las ideologías radicalmente anti-religiosas que acepten una ética exclusivamente intersubjetiva y las religiones integristas que basan su legitimidad en una normatividad enteramente trascendental, ahistórica y acrítica. Tanto los caricaturistas de Mahoma como la masa que protestaba contra los dibujos se aproximan o simpatizan con una $u$ otra de estas posturas, y por ello ignoran y reducen la complejidad religiosa a una cuestión de derechos o se dejan guiar por una ideología populista respectivamente. Esta aparente oposición se resuelve desde la perspectiva antropológica religiosa, en cuanto que la religiosidad se concibe

106 Según Habermas: "Wenn man ... das demokratische Verfahren ... als eine Methode zur Erzeugung von Legitimität aus Legalität begreift, entsteht keine Geltungsdefizit, das durch "Sittlichkeit" ausgefüllt werden müsste". Según Ratzinger: “...dass es Pathologien in der Religion gibt, die höchst gefährlich sind und die es nötig machen, das göttliche Licht der Vernunft sozusagen als ein Kontrollorgan anzusehen, von dem her sich Religion immer wieder neu reinigen und ordnen lassen muss, ... Aber ... auch Pathologien der Vernunft gibt, ... Deswegen muss ... auch die Vernunft an ihre Grenzen gemahnt werden und Hörbereitschaft gegenüber den grossen religiösen Überlieferungen der Menschheit lernen." Jürgen Habermas/Joseph Ratzinger, Dialektik der Säkularisierung. Über Vernunft und Religion (Freiburg: Herder, 20055), pp. 20 \& 56 (cursivas en texto original). 
como relacionalidad inconmensurable, dialéctica y dialógica que habilita al hombre para constituirse en sociedad. Las religiones y las ideologías desarrollan estas dimensiones según sus normativas internas pero en un concreto contexto histórico y cultural. Ninguna goza entonces del monopolio de interpretación (Habermas), mas están llamadas a una complementariedad: a aclarar los valores y normas conocidas o intimadas por todos para que el mundo se mantenga unido (Ratzinger) ${ }^{107}$. La tarea que toca a las ideologías y religiones es un aprendizaje mutuo. ¿Están dispuestas a andar este camino? Al parecer el Islam nos invita a embarcarnos en él.

En el nombre de Dios, muy bueno y misericordioso.

Alabado sea Dios, Señor del universo,

Muy bueno y misericordioso.

Soberano del Día del Juicio.

A ti te adoramos. A ti te pedimos ayuda.

Guíanos por el Camino Recto,

El camino de aquellos a los que concediste tus beneficios

$Y$ no de los que incurrieron en tu cólera

Ni de los que están extraviados. 108

Peter G. Pandimakil OSA

Estudio Teológico Agustiniano, Valladolid

Saint Paul University, Ottawa

03 de octubre de 2006

107 Véase: JÜRgEn HABERMAS/JosePh RATZINGER, Dialektik der Säkularisierung, pp. 34-36 \& 56-58.

108 La fatiha/apertura del Corán. 